\title{
Exchange Market Mayhem: The Antecedents and Aftermath of Speculative Attacks
}

June 21, 1995

\section{Barry Eichengreen, Andrew K. Rose, and Charles Wyplosz*}

\begin{abstract}
This paper uses graphical techniques and multinomial logit analysis to evaluate the causes and consequences of episodes of turbulence in foreign exchange markets. Using a quarterly panel of data from 1959 through 1993 for twenty OECD countries, we consider the antecedents and aftermath of devaluations and revaluations, flotations, fixings, and speculative attacks (which may not be successful). We find that realignments of fixed exchange rates are alike: devaluations are preceded by political instability, budget and current account deficits and fast growth of money, and prices. Revaluations are mirror images of devaluations. These movements are largely consistent with the standard speculative attack model. In contrast, few consistent correlations link regime transitions like flotations or fixings to macroeconomic or political variables. Transitions between exchange rate regimes are largely idiosyncratic, and are neither consistently provoked ex ante by systematic imbalances, nor typically justified ex post by subsequent changes in policy. We conclude that there are no clear early warning signals of many speculative attacks, and no easy solutions for policy-makers.
\end{abstract}

Barry Eichengreen

CEPR, NBER and

Department of Economics

U.C. Berkeley, Evans Hall

Berkeley, CA 94720

Tel: (510) 642-2772

Fax: (510) 643-0926

eichengr@econ.berkeley.edu

\begin{tabular}{|c|c|}
\hline Andrew K. Rose & Charles Wyplosz \\
\hline CEPR, NBER and & CEPR, and \\
\hline Haas School of Business & INSEAD, Boul de \\
\hline U.C. Berkeley & ince, Fontainebleau \\
\hline Berkeley, CA 94720-1900 & 77305 France \\
\hline Tel: (510) 642-6609 & Tel: +33 (1) 60724234 \\
\hline $\begin{array}{l}\text { Fax: (510) 642-4700 } \\
\text { arose@ @haas.berkeley.edu }\end{array}$ & $\begin{array}{l}\text { Fax: +33 (1) } 60724242 \\
\text { wyplosz@insead.fr }\end{array}$ \\
\hline
\end{tabular}

Keywords: exchange rate; balance of payments; devaluation; flotation; fixing; crisis; logit. JEL Classification Numbers : F31, F32.

* Barry Eichengreen is John L. Simpson Professor of Economics and Professor of Political Science at the University of California, Berkeley, Research Fellow of the CEPR and Research Associate of the NBER. Andrew Rose is Associate Professor and Chair of Economic Analysis and Policy at the Haas School of Business, University of California, Berkeley, Research Fellow of the CEPR and Research Associate of the NBER. Charles Wyplosz is Professor of Business at INSEAD and Research Fellow of the CEPR. This paper was marked by many visits: Eichengreen at the Federal Reserve Board; Rose and Wyplosz at the IMF; and Rose at the U.S. Department of Treasury, ECARE, and IIES. For sterling research assistance we thank Chang-Tai Hsieh. We have floated some of our ideas by Michael Dooley, Jeffrey Frankel, Paul Krugman, and participants at the 1995 FRBSF/CEPR Conference, IIES and U.C.S.C.; we are grateful for their frank remarks. The sensible comments pounded in by David Begg, Bernard Dumas, Axel Weber, and the Economic Policy panel have helped to fix many problems. The STATA 4.0 programs and data used in this analysis are available for a year following publication, upon receipt of a self-addressed stamped mailer with four 3.5" formatted high-density diskettes. 


\section{Introduction}

The exchange rate is the chink in the armor of modern-day macroeconomic policymakers.

Be it Italy and the United Kingdom in 1992, France in 1993, Mexico in 1994 or Spain in 1995, speculative pressures and the dire consequences of the policy responses required to defend the exchange rate can bring a government's entire macroeconomic strategy tumbling down. Countries like Sweden in 1992, which raised central bank lending rates to 500 per cent in a futile attempt to defend its currency peg, have been forced by speculative attacks to concede and radically reorient their policies. Countries like Mexico, which attempted to devalue in advance of the crisis, have destroyed investor confidence, provoked capital flight and ignited a financial-market meltdown. Even the United States, a relatively large closed economy committed to a policy of benign neglect, was forced in 1994-95 to consider sacrificing other policy goals on the altar of the exchange rate when the dollar declined precipitously against the yen. Without realizing it, many observers have derived an impossibility theorem: neither pegging like Sweden, nor occasionally realigning like Mexico and the EMS countries, nor floating like the United States is a tolerable option. Policymakers seem to retain no acceptable international monetary alternative.

The more optimistic view is that countries experiencing severe exchange-market difficulties are not drawn at random from the underlying population. Those whose pegged rates are attacked, whose realignments destroy rather than strengthen investor confidence, and whose floating rates are buffeted by exchange market turbulence are countries which recklessly pursue inappropriate policies and thereby bring exchange market difficulties upon themselves. Thus, the speculative attacks on Italian lira, British pound and Spanish peseta in 1992 have been attributed to inadequately restrictive 
monetary and fiscal policies. ${ }^{1}$ Mexico's difficulties were anticipated, at least in some circles, by observers who warned that the stability of the peso was threatened by excessive inflation and unsustainable current account deficits. ${ }^{2}$ The weakness of the dollar has been blamed on low domestic savings and on the Fed's having waited too long to raise interest rates. By implication, governments can escape exchange market difficulties if they only avoid policy mistakes. Sinners are justly punished by financial markets and foreign exchange market difficulties are simply a reflection of policies gone awry.

If unsustainable fundamentals are responsible for speculative attacks, then eliminating the latter is straightforward, once the former have been identified. One of the objectives of this paper is to see whether there is indeed a set of politico-economic fundamentals which are sensibly and consistently linked to speculative attacks. We consider a wide array of variables in our search for "early warning" signs of trouble brewing. ${ }^{3}$ But not all speculative attacks may be warranted by fundamental forces. If some attacks are self-fulfilling -- i.e., some of the "innocent" are slaughtered, while not all of the "guilty" suffer -- then the policy prescriptions become much more difficult.

Whether policymakers make mistakes or are subjected to speculative attacks on their currencies through no fault of their own, there is the question of what to do when crisis strikes. Should governments resist speculative pressures and defend the currency at all cost, or should they

1 See for example Bank for International Settlements (1993), Commission of the European Communities (1993), Committee of Governors of Central Banks (1993a,b), Goldstein et al. (1993).

2 See, e.g., Dornbusch and Werner (1994).

3 The IMF has recently moved towards a consensus in favor of close monitoring of countries with potential financial crises, by means of an early warning system; see the Financial Times April 27, 1995. 
regard market pressures as irresistible and bow to the inevitable? If they give in, should they respond by realigning, widening the fluctuation band, or floating? While such hypothetical questions are properly the domain of theoretical analysis, we provide some insights by analyzing the positive question of what has actually happened following a variety of different exchange rate events, such as devaluations and flotations.

These are among the most fundamental questions of macroeconomic policy in today's world of international capital mobility. And since financial markets will continue to grow, frustrating the efforts of policymakers to contain them, they are certain to be among the preeminent policy issues of coming years.

Our goal in this paper is to provide a guide for the perplexed policymaker by supplying answers to questions like the following. Are there significant differences in the observed behavior of economic and political variables in periods leading up to episodes of exchange market crisis and in placid periods? Are there economic and political actions that policymakers must forego to avoid exposing the ir currencies to speculative attack? Are there significant differences in the post-attack behavior of economic and political variables depending on whether the authorities respond by defending, devaluing or floating the currency? How, in short, should policymakers manage turbulence in foreign exchange markets?

Given that these are among the most basic questions in all of international macroeconomics, it is striking that we possess so little systematic empirical analysis on which to base policy advice. There is a literature on the effects of currency devaluation (Cooper 1971, Kamin 1988, Edwards 1989, 1993), but most of the episodes it considers are drawn from earlier periods in which financial 
markets were less well developed and capital controls were pervasive. None of these studies takes into account the authorities' choice between devaluing, floating and widening their currency bands in response to an attack, much less for the efficacy of the alternative responses. Most importantly, these studies fo cus on exchange rate changes per se rather than currency crises; that is to say, they include exchange rate changes not preceded by speculative attacks and exclude attacks that were successfully repelled. For our purposes, this is a source of selectivity bias in whose presence inferences about the consequences of speculative attacks may be misleading.

The literature on the causes of currency crises is even spottier. A few studies (Blanco and Garber 1986, Cumby and Van Wijnbergen 1989) have asked whether attacks on particular currencies (e.g. the Mexican peso in the 1970s, the Argentine peso in the 1980s) can be explained by lax monetary and fiscal policies, as predicted by standard macroeconomic models. But aside from our own previous work (Eichengreen, Rose and Wyplosz 1994a,b), we know of no recent studies that compare the evolution of macroeconomic variables in periods leading up to speculative attacks and in a control group of tranquil, non-attack periods.

In this paper we extend that previous work and draw out its policy implications. We examine a large panel of twenty industrial countries since the restoration of current account convertibility at the beginning of 1959 . Where our previous study considered only periods when exchange rates were pegged within pre-announced bands, here we analyze the causes and consequences of turbulence affecting both pegged and floating rates. ${ }^{4}$ By considering a wider

\footnotetext{
${ }^{4}$ Anyone who doubts that floating exchange rates can be attacked has merely to think of the movements of the American dollar in the Spring of 1995.
} 
variety of economic variables, including labor market variables like employment, unemployment and wages, we more clearly distinguish between different explanations for speculative attacks.

In addition to analyzing the behavior of macroeconomic variables, we consider political conditions directly. We ask whether speculative attacks are more likely to occur before or after elections and government changes, whether they are more likely to be directed at unstable or minority governments, and whether left - or right-wing governments are more susceptible to their effects. We ask how much political variables contribute to explaining the incidence of speculative attacks after controlling for macroeconomic policies. Are economic indicators a sufficient statistic to warn of impending currency crises, in other words, or do political variables have additional explanatory power?

Our previous papers were essentially static, limited to the periods around crises. In contrast, here we analyze both the prelude and aftermath of attacks. We ask how the post-crisis development of macroeconomic and political variables is affected both by the pre-attack behavior of those variables and by policymakers' response to the crisis. Where our earlier papers took a univariate approach to analyzing the data (comparing the behavior of individual variables, one at a time, during speculative attacks and periods of exchange market tranquillity), here we embed our analysis in a multivariate, multinominal framework. We ask whether it is possible to discern differences in the joint behavior of groups of economic and political factors across a variety of different exchange rate episodes. We emphasize that devaluations, decisions to float (or fix) the exchange rate, decisions to widen the band, and success in repelling successful attacks are all alternatives and analyze them jointly in the appropriate multinominal framework. We study the 
behavior of macroeconomic and political variables in both the run-up to and the aftermath of various developments in financial markets -- devaluations, flotations, unsuccessful attacks, and so forth -- in an integrated fashion. In other words, our analysis is dynamic, multivariate, and multinomial, though non-structural.

The findings are striking. We identify persistent, significant movements in a variety of macroeconomic variables both preceding and following currency devaluations and revaluations. For instance, money and credit growth are high preceding devaluations (compared with periods of tranquillity), as are wage and price inflation; both current accounts and governments tend to be in deficit. After the actual event, these tendencies are reversed. These movements are consistent with the predictions of standard models from open-economy macroeconomics that have long guided policy formulation. They suggest that governments devalue for good reasons having to do with external imbalances, and that devaluations generally have the hoped-for effects. This is a first key finding: standard models describe realignments of fixed exchange rates relatively well; many adjustments to pegs seems warranted; and the adjustment process seems to work.

Not all devaluations are preceded by speculative attacks, however; and not all attacks are successful. There is no presumption, in other words, that actual devaluations resemble exchange rate crises. Indeed, when we turn from devaluations to speculative attacks (whether successful or not), we find more heterogeneity. Some macroeconomic variables move in the fashion predicted by fundamentals-based models of speculative attacks. Attacks are preceded by relatively rapid rates of money and credit growth and rapid inflation. But the imprecision (manifest in the two standard deviation bands) is high, indicative of considerable heterogeneity. And other macroeconomic 
variables do not move in the direction predicted by fundamentals-based models. Moreover, there are few significant differences in the behavior of these variables when we divide crises into successful and unsuccessful attacks. This suggests that while some attacks are plausibly motivated by imbalances in fundamentals, others are not. This conclusion is consistent with the notion that some attacks are of the purely self-fulfilling variety.

That there is uncertainty about when and where speculative attacks occur should be intuitively plausible. Policymakers -- and market participants -- are often taken by surprise by the outbreak of crisis. After all, if crises were readily avoidable, why would we continue to observe so many episodes that severely damage the standing of politicians and governments? That the timing of crises is hard to predict is consistent with the conclusions of Rose and Svensson (1994) that macroeconomic fundamentals are of little use for explaining the credibility of EMS parities and of Eichengreen and Wyplosz (1993) that fundamentals did not obviously predict the timing of the 1992 attack on the EMS.

The behavior of a number of macroeconomic variables varies systematically between actual realignments and tranquil periods, and the standard early-warning signals precede devaluations. However, the same cannot be said of regime transitions such as exchange rate flotations, fixings, and other innovations (such as changing band widths). Transitions between exchange rate regimes are so heterogeneous that it is difficult to distinguish them systematically from periods of tranquillity. This is our second major finding: while exchange rate realignments are alike in many respects, regime transitions are idiosyncratic. And since it is difficult to know ex ante whether a fixed exchange rate under attack will be devalued or floated (or for that matter, successfully defended), 
there do not appear to be clear early-warning signals which precede changes in exchange rate regimes and unsuccessful speculative attacks.

Further, regime transitions like flotations or fixings of exchange rates do not vary systematically from periods of tranquillity before, during or after the change in regime. It seems prima facie reasonable to believe that many regime transitions are neither warranted by fundamental economic imbalances, nor justified by subsequent policy switches. We find little evidence that devaluations or changes in exchange rate regimes are followed by dramatic loosenings of e.g., fiscal or monetary policy. If there exist multiple equilibria in exchange rate regimes so that attacks can be successful even without fundamental imbalances, there are few signs that governments switch policies in response to these unwarranted regime changes.

Succinctly, the data suggest to us that the international financial syste m works well in dealing with realignments of fixed but adjustable exchange rates, but poorly when it comes to transitions between regimes.

From a policy point of view, our findings reinforce the feeling that there exist no easy solutions to the exchange rate dilemma. There are no unambiguous early-warning signals of impending crisis. Governments which follow traditional conservative policies cannot be assured of insulation from speculative attacks; alternatively, there are no clearly "right" policies. It would appear that exchange rates can be, and repeatedly are, severely strained and destabilized by speculative pressures even in the absence of clear imbalances in macroeconomic fundamentals. ${ }^{5}$

${ }^{5}$ Similarly, governments that give in to speculative attacks are not always clearly punished by higher interest rates or inferior economic performance subsequently. 
These implications are not heartening for those who advocate the establishment of exchange rate target zones (Williamson and Henning 1994) or the re-establishment of a Bretton-Woods-style system of pegged-but-adjustable rates (Bretton Woods Commission 1994). They suggest that following the "right" policies may not be enough to support the operation of such schemes. Our results will also disappoint those who favor the continued maintenance of the European Monetary System during the transition to EMU, for they imply that the EMS system of adjustable bands can be strained and destabilized even in the absence of overt policy imbalances. They point to a limited menu of options for improving the operation of the exchange-rate system: (1) monetary union a la Maastricht, which promises to eliminate exchange rate instability by abolishing the exchange rate at least over a limited domain; ${ }^{6}(2)$ a transactions tax or its equivalent on foreign currency dealing to provide policymakers insulation from market pressures; and (3) learning to live with the current hybrid system of dirty floating interspersed with irregular groupings of fixed rates. All of these options have drawbacks. None is wholly attractive. Our conclusion is that there unfortunately exists no alternative.

${ }^{6}$ While there remain grounds for thinking that certain members of the European Union may succeed in completing the transition to monetary union on the time table laid out in the Maastricht Treaty, there is little reason to think that exchange rate instability will be eliminated over a wider area by establishing a single currency for the industrial countries (as suggested in Cooper 1990), much less the entire world (Bergsten 1994a). Another way of attempting to eliminate the problem is by establishing a currency board, which is designed to remove from the government all discretion over the exchange rate and to completely subordinate other economic policies to that exchange rate target. As the recent experience of Argentina shows, however, a statutory currency board is no automatic guarantee of credibility in a politicized environment. See Eichengreen (1994) for further discussion. 
The paper is organized as follows. Section 2 reviews what the literature in economics has to say about the causes and consequences of speculative attacks. Section 3 provides a brief description of the data set. The heart of our paper is Section 4, in which we use graphical techniques to explore the empirical regularities of macroeconomic data around periods of devaluations, flotations, speculative attacks and a variety of other exchange rate events. Section 5 provides a more statistical treatment. Section 6 draws out their policy implications.

\section{Literature}

In this section we review what the literature in economics has to say about the causes and consequences of speculative attacks. Following a review of the standard approach, we focus on the literature which postdates the 1992 EMS crisis and highlights non-standard channels through which speculative pressure can be transmitted to the foreign exchange market.

\subsection{The Traditional Approach}

The standard approach to balance-of-payments crises follows Krugman (1979). ${ }^{7}$ In the canonical Krugman model, the authorities peg the exchange rate until their reserves are exhausted, at which point they float the currency. With the government pegging the relative rate of return on domestic- and foreign-currency-denominated assets (in Krugman's model, the exchange rate), investors hold domestic and foreign assets in fixed proportions. When they rebalance their

7 Krugman's model is an adaptation of the Salant and Henderson (1978) model of buying attacks on commodity price stabilization schemes. 
portfolios by selling an incipient excess supply of domestic assets for foreign exchange, the central bank is forced to intervene, using reserves to prop up the exchange rate.

Krugman assumed that government budget deficits were at the root of speculative attacks on pegged currencies. In his model, all budget deficits are financed with domestic credit. Since investors exchange only a portion of the incremental supply of domestic credit (portfolio proportions remaining constant), the shadow exchange rate (which would prevail in the event that the pegging policy is abandoned) depreciates gradually over time. When it equals the current exchange rate, investors attack the peg, depleting the remaining reserves, for to do otherwise would make available arbitrage profits and imply market inefficiency.

The empirical implication is that we should observe expansionary fiscal and monetary policies prior to speculative attacks. Such policies should be accompanied by the steady erosion of reserves.

Krugman's model has been extended to incorporate deviations from purchasing power parity (so that pre-attack fiscal expansions are accompanied by increasingly overvalued real exchange rates, rising real wages, growing relative unit labor costs, current account deficits), capital controls (which lengthen the period of time for which a currency peg can be maintained given the stance of monetary and fiscal policies), and uncertainty about monetary and fiscal policies (the greater the uncertainty, the faster reserves will be depleted, since the probability of a burst in domestic credit creation which causes the shadow exchange rate to depreciate below the current rate is correspondingly increased), and portfolio optimization by investors (in which case the assumption that domestic and foreign assets are held in fixed proportions prior to the attack can be 
relaxed, implying accelerating losses of central bank reserves as investors hedge against a currency crisis). ${ }^{8}$ These extensions suggest additional regularities that should be evident in the run-up to attacks: overvalued real rates, higher real wages, rising relative unit labor costs, significant policy uncertainty, current account deficits, and accelerating reserve losses. In our empirical work, we search for all of these regularities.

Krugman's formulation carries over to crawling pegs and managed floats under which the authorities do not peg the level of the currency but commit to an intervention strategy framed as a path for the exchange rate. ${ }^{9}$ Thus, the same general model can be used and the same empirical predictions derived for attacks on a variety of exchange rate arrangements. Again, the implication is that countries which suffer exchange rate instability and/or rapid depletion of their reserves should be those whose policy is excessively expansionary and uncertain, in which the real exchange rate indicates overvaluation, and where the absence of capital controls allows the markets to capitalize on the consequences.

For a few countries with histories of high inflation (Mexico and Chile in the 1970s; France and Italy in the early 1980s), the predictions of these models broadly fit the facts. ${ }^{10}$ Yet there are also cases in which monetary and fiscal imbalances are not clearly apparent in the period leading up

8 For models which treat the pre-attack behavior of wages, prices and real exchange rates, see Goldberg (1988) and Willman (1988). On the consequences of capital controls in the Krugman model, see Wyplosz (1986). Penati and Pennacchi (1989) analyze speculative attacks in a model of optimal portfolio choice. Models which treat uncertainty explicitly include Flood and Garber (1986a) and Claessens (1991).

9 See for example Connolly and Taylor (1984) and Connolly (1986).

10 See for example Cumby and Van Wijnbergen (1989) and Penati and Pennacchi (1989) on developing countries, Thomas (1994) on Italy and France. 
crises. Eichengreen and Wyplosz (1993) argue this for many countries affected by the ERM crisis in 1992, for example. ${ }^{11}$ Rose and Svensson (1994) show that, for a variety of European currencies, measures of realignment expectations (interest differentials purged of the effect of expected exchange rate movements within the band) are little affected by the prior and contemporaneous movement of the economic fundamentals to which the traditional theoretical models point. ${ }^{12}$

\subsection{Recent Theoretical Developments}

These observations prompted the development of a subsequent generation of theoretical models whose assumptions and predictions depart from those of the canonical Krugman model. An example is Ozkan and Sutherland's (1994) model of the ERM crisis. In that model, there may be no evidence of monetary and fiscal imbalances in the period preceding the crisis. In contrast to Krugman's assumptions, the authorities may be following macro policies consistent with the indefinite maintenance of the prevailing currency peg. Assuming the continued pursuit of those policies, there is no reason to anticipate the eventual exhaustion of international reserves, in other words. But if those policies are associated with high and rising unemployment (perhaps for reasons beyond the authorities' control, including reasons originating outside the country), a government whose survival probability is negatively affected by unemployment and which can reduce unemployment by shifting to more expansionary policies may be induced to abandon the currency peg. Anticipating this

11 See also Portes (1993) and Obstfeld (1994).

12 One exception, to this generalization is inflation differentials, which do display some association with realignment expectations in the Rose-Svensson study (consistent with the findings of the literature). Thomas (1994) finds that some measures of fundamentals significantly predict realignment expectations for France but not for Italy. Their effect is stronger when the deviation of 
eventuality, speculators may attack in advance of the policy shift. Thus, where the Krugman model focused on the determinants of external balance, the Ozkan-Sutherland model focuses instead on the decisions of governments concerned with internal balance and constrained by the exchange rate in their choice of policy response.

In this formulation, the crisis need not be preceded by expansionary monetary and fiscal policies or by the imminent exhaustion of reserves. Rather, one should observe rising unemployment and other domestic economic developments of concern to the authorities. These predictions are consistent with European experience in 1992-93, when speculative attacks coincided with a deepening recession that aggravated existing levels of unemployment. Caramazza (1993) and Drazen and Masson (1994) consider data for France, finding that unemployment positively affe cted realignment expectations ever since 1987, a result confirmed by Thomas (1994). Masson (1995) studies the UK and similarly concludes that persistent high unemployment increased the perceived probability that the government would abandon the sterling parity. ${ }^{13}$ To shed light on such issues, we look at a variety of measures of political variables jointly with labor market conditions in our empirical work.

The Ozkan-Sutherland model, in which events abroad can raise domestic unemployment and induce an optimizing government to abandon the currency peg, provides one channel through

the exchange rate from the central parity is included in the specification. In any case, Thomas concurs with Rose and Svensson in concluding that the effect of fundamentals is uniformly small.

13 Until more country studies are conducted, the generality of these results remains an open question. This raises the general issue of whether country-specific effects are important for the incidence of speculative attacks, a question which it is possible to address using the empirical framework we develop below. 
which developments external to a country can provoke a currency crisis. Gerlach and Smets (1994)

introduce others. In their model, a speculative attack which leads to devaluation by one country

may threaten the competitiveness of a trading partner. This argument has been invoked for Ireland

and Portugal in 1993, whose positions were said to be undermined by the depreciation of the pound

sterling and the Spanish peseta, respective ly. ${ }^{14}$ The empirical implications of their analysis again

differ from those of the Krugman model. Here, there may be no evidence of budget deficits, rapid

monetization, overvaluation, current account deficits or reserve losses in the period leading up to the

attack. But once the neighboring country devalues, observers revise their assessment of the likely

future evolution of these variables and attack the other currency as well; an infectious contagion of

exchange rate crises may break out. As in the Ozkan-Sutherland framework, the attack may

precede rather than follow imbalances in domestic fiscal policies and current accounts, although the

Ozkan-Sutherland and Gerlach-Smets models provide different predictions about which other

variables (unemployment in the first case, a successful attack on a major trading partner in the

second) behave distinctively in the pre-attack period. We document the extent of "contagion"

effects below in our empirical work. ${ }^{15}$

14 Again in 1995 the realignment of the Portuguese escudo was blamed on exchange market difficulties culminating in realignment in neighboring Spain.

15 Honohan and Conroy (1994) document the strong effect of the sterling- Irish pound rate on the Irish pound/DM rate during the EMS period, which is consistent with the predictions of models of spill-over effects. Their analysis is less than an ideal test, however, for it focuses on the impact on interest differentials rather than realignment expectations (interest differentials purged of the contribution of expected exchange rate movements within the band) and because their specification does not also include other obvious fundamentals. More generally, a prediction of these models, which we can test using our data, is that exchange market crises and events should be clustered in time. 
Another channel is information effects, in whose presence the collapse of one currency may convey information about the collapse of a second. Eichengreen and Wyplosz (1993) describe how speculative attacks which drove a subset of EC countries out of the ERM in 1992, by dimming the prospects for early monetary unification, conveyed information about the preparedness of other countries to defend their currency pegs. When this channel is operative, we might expect to see evidence of monetary and fiscal imbalances in a particular country in the period leading to a wave of speculative attacks.

Yet another possibility is that there exist multiple equilibria in foreign exchange markets and that the collapse of one currency coordinates expectations so as to shift the market from one equilibrium to another. Flood and Garber (1984b) and Obstfeld (1986) were the first authors to link multiple equilibria to speculative attacks. ${ }^{16}$ In their models, multiple equilibria exist in the foreign exchange market because of the contingent nature of the macro-policy rule. In the absence of an attack, monetary and fiscal policies are in balance, and nothing precludes the indefinite maintenance of the prevailing peg. There is no reason to anticipate reserve losses and other indications of real overvaluation in the period leading up to the attack. If and only if the currency is attacked, however, the authorities switch to more accommodating monetary and fiscal policies consistent with a lower level for the exchange rate. Thus, speculative attacks can be self-fulfilling. One of our objectives in

16 Barnett and Ho (1995) generalize this point about the possibility of multiple equilibria. Note that this is different from the previous example, which is not one of multiple equilibria as it is described in the preceding paragraph. If we assume that the first countries to be driven out of the ERM suffered that fate because of Krugman-like imbalances in economic fundamentals, then there is existed a unique equilibrium toward which the system was heading. (The countries with imbalances in fundamentals would have inevitably exhausted their reserves and been forced to devalue, impelling the others to follow.) 
this paper is to examine the actual behavior of e.g., monetary and fiscal variables to search for empirical manifestations of policy switches, and characterize them as being frequent or atypical. ${ }^{17}$

In the early multiple-equilibrium models of Flood-Garber and Obstfeld, the assumption of a contingent policy process (of a monetary policy that shifts in a more expansionary direction only in the event of an attack) was ad hoc. Obstfeld (1994) and Bensaid and Jeanne (1994) add the relevant micro-foundations. Bensaid and Jeanne appeal to the Barro-Gordon (1983) model, assuming that an increase in the unemployment rate raises the costs to the government of continuing to pursue policies of price stability. ${ }^{18}$ When the public observes unemployment, it revises upward its forecast of the probability that the authorities will deviate in order to reflate the economy; this in turn requires the authorities to raise the discount rate to defend the currency, which only serves to aggravate their unemployment problem.

This positive feedback has two implications. One is that a small rise in unemployment can provoke a crisis, since that rise in unemployment will require the adoption of policies that will aggravate the initial problem in a vicious spiral, and the markets can be expected to anticipate the

17 In the Flood and Garber (1984b) and Obstfeld (1986) formulations, the contingent nature of the money supply rule opens up the possibility of self-fulfilling attacks. But the same general result obtains if one assumes contingent processes for other policy instruments. For example, Dellas and Stockman (1993) show that multiple equilibria can obtain if an attack induces a government to impose capital controls on a regime of otherwise free international capital mobility. Uribe (1995) similarly shows that if the authorities adopt a real exchange rate rule, increasing the devaluation rate when the real exchange rate is below its long-run level and vice versa, there is again scope for selffulfilling expectations.

18 Obstfeld describes a number of other channels through which an attack on a currency which forces the authorities to raise interest rates may thereby induce them to abandon the exchange rate peg: the impact of higher interest rates on the cost of public debt service, an induced increase in non- 
operation of that negative feedback in advance. The other is that speculative attacks can be selffulfilling. If speculators, for whatever reason, lose confidence in the official commitment to defend the currency peg, the government will be forced to raise interest rates, which will create actual or expected unemployment and thereby further undermine confidence in the government's commitment to pursue policies of price stability, requiring further interest rate hikes, further aggravating unemployment and so on, until the currency collapses. If this process is sufficiently swift, periods of speculative attacks may look indistinguishable from periods of tranquillity in the data. ${ }^{19}$

The question for models with multiple equilibria, as Grilli (1986) emphasizes, is what coordinates the expectations and actions of market participants. So long as speculators do not attack, the exchange rate can be maintained forever, but whenever many traders sell the currency simultaneously, the peg collapses. If there exists a single large trader in the foreign exchange market, he can collapse the peg at any time; but if there are a large number of small, credit-constrained traders, they must move simultaneously to mobilize an attack of magnitude sufficient to shift the system from one equilibrium to another. Gerlach and Smets suggest that traders may use prominent events, like turbulence in foreign exchange markets and successful attacks on other countries, as focal points for coordinating their actions. This notion has been invoked, for example, to explain why ratification referenda on the Maastricht Treaty seemed to be associated with speculative attacks

performing bank loans and hence bank failures, and a rise in the cost of indexed mortgage debt. A survey and synthesis of the relevant literature is provided by Jeanne (1994).

19 Similar dynamics arise in Obstfeld's (1994) optimizing model because the cost of servicing the public debt depends positively on the interest rate. Hence, a loss of confidence which must be met by interest rate hikes can so worsen the fiscal position to provoke a self-fulfilling attack. See also Lehment (1994). 
on EMS currencies. ${ }^{20}$ Empirically, if the coordinating devices which trigger speculative attacks differ over time, speculative attacks may look idiosyncratic rather than similar; we may also expect to see clustering of attacks over time (a phenomenon sometimes known as the "contagion" effect).

For a given set of macroeconomic fundamentals, then, it is equally possible for an attack to occur or not depending on how market participants expect one another to react, and how they expect government to react to their reactions. These models thus point to strategic behavior by traders and governments as determinants of the incidence of speculative attacks. In the same way that a devaluation in a neighboring country can serve as a focal point inducing speculative sales, intervention can serve as a focal point encouraging speculators to withdraw from the market. ${ }^{21}$ One can equally well imagine, however, intervention might encourage bear speculation if currency traders have reason to believe that the costs of intervention rise with its magnitude. Assume for example that the authorities defend the currency by raising the interest rate but that the marginal cost to the government of raising the rate rises as the rate scales higher levels. Then speculative sales met by interest-rate increases may cause currency traders to revise downward their estimate of the

${ }^{20}$ See Gerlach and Smets (1994) and Eichengreen and Wyplosz (1993). The latter report a survey of foreign exchange traders, the results of which can be interpreted in terms of this focal-point notion.

${ }^{21}$ One might think that this possibility is especially plausible if intervention is coordinated with other countries. This information effect is distinct from the impact of foreign borrowing, and foreign support generally, on the exchange reserves of the government under attack. Buiter (1987) shows that foreign borrowing does not unambiguously delay the timing of an attack; besides increasing the resources at the authorities' command, borrowing increases a country's foreign indebtedness, implying a larger eventual devaluation and therefore a greater incentive for an early attack on a country with Krugman-like imbalances in fundamentals. 
government's capacity to further defend the currency and encourage them commit additional resources to its attack. ${ }^{22}$

Chen (1995) models these dynamics in a world inhabited by a single central bank and a single Soros-like speculator. ${ }^{23}$ The flow costs of currency sales by the speculator and intervention by the government are assumed to increase with their respective magnitudes. The benefits to each depend on the level of the exchange rate, whose movement depends on the ratio of speculative sales to intervention. Solving for the subgame perfect equilibrium, Chen shows that there can exist a stable zone around the middle of a currency's fluctuation band within which it is in the interest of neither the trader nor the government to enter the foreign exchange market. But an accumulation of small shocks that pushes the currency out of that zone and toward the edge of its band may induce the trader to initiate speculative sales. Intuitively, shocks have already done part of the work of pushing the currency out of its band without requiring the trader to incur costs. The government, in other words, is forced to engage in costly intervention to limit the effect of those shocks. The trader having acquired a cost advantage relative to the government, the former may conclude that it is advantageous to force the issue. In this model, small shocks which shift the exchange rate within the band may set off large speculative attacks. These predictions are consistent with recent evidence that the position of the exchange rate within the band is a strong indicator of market expectations of

22 As mentioned above, Lehment (1994) provides a model of these dynamics.

23 Assuming multiple speculators adds the questions about coordination addressed in previous paragraph. Chen's framework is an application of the Markov differential game model of patent races by Budd, Harris and Vickers (1993). 
realignment (Caramazza, 1993; Chen and Giovannini, 1993; Cuikerman, Kiguel and Leiderman,

1993; Rose and Svensson, 1994; Thomas 1994).

One can approach this problem from the viewpoint of strategic behavior among

governments as well. Melitz (1994) provides a model of a strategic game between two

governments which use interest rate policy to support their currencies and achieve other objectives.

Country A may wish to reduce its interest rate and be able to do so without destabilizing its

exchange rate if Country B responds in kind. But if Country B fails to respond, Country A's interest

rate reduction may provoke an attack on its currency. This model is compatible with those

described above that are driven by information revelation: the interest rate reduction by Country A,

by failing to elicit a sympathetic response by Country B, reveals information about the latter's

commitment to supporting Country A's exchange rate. Again, the attack on Country A's currency

can occur in the absence of obvious imbalances in macroeconomic fundamentals. ${ }^{24}$

This recent research highlights the possibility that political variables, rather than narrowly

macroeconomic ones, play a critical role in speculative attacks. It implies, for example, that left-

wing governments may be more inclined than their right-wing counterparts to abandon a currency

peg in response to rising unemployment. ${ }^{25}$ Governments with small parliamentary majorities may be

particularly susceptible to pressure to abandon the prevailing currency peg in response to additional

${ }^{24}$ Melitz applies this model to the attack on the French franc in the summer of 1993, when French interest rate reductions did not elicit the expected German response, causing market participants to revise their views of the depth of Germany's commitment to the maintenance of the franc-DM rate and the monetary union project. 
unemployment (because, for example, they are most likely to fall as a result of a vote of no confidence by their unemployment-adverse constituency if joblessness rises). Even upon controlling for the size of the governing majority, governments with short expected life spans may be most likely to abandon a currency peg in response to additional unemployment (since short-lived governments benefit the least from an enhanced reputation for defending the parity in the future and suffer the most from unemployment now). Crises may occur before elections if governments are prone to reflate the economy in order to enhance their chances of victory (Rogoff and Siebert, 1988) or after changes in government if the markets are uncertain of the new cabinet's commitment to defending the currency. But while considerable attention has been paid to how such variables affect inflation rates, budget deficits and public debts (see, inter alia, Grilli et al. 1991 and Roubini and Sachs 1988), little if any work has been done to date on the political determinants of currency crises.

Much the same is true of the opposite direction of causality. Political variables can be affected by and affect exchange market outcomes. Cooper's famous 1971 study found that currency devaluation was a leading indicator that an incumbent finance minister would be removed from office. More generally, exchange market turmoil is frequently interpreted as an indication of the government's macroeconomic incompetence and as a leading indicator of an impending electoral defeat. But whether such relationships hold systematically has yet to be studied.

The recent literature says relatively little about what can be done to contain market pressures. One exception is Ozkan and Sutherland (1995), who analyze the effects of capital

25 Alesina and Tabellini (1989) find that left-wing governments are more inclined to impose capital controls, which is one of the events in response to which capital outflows and a speculative crisis may occur. 
controls in a model of an optimizing government seeking to maintain an exchange rate peg.

Controls, by reducing the impact of foreign interest rates -- and foreign exchange market

transactions generally -- on domestic interest rates can directly effect the policymaker's decision of whether to abandon the currency peg. In addition to this direct effect, there is an indirect effect operating through expectations: currency traders realize that the presence of controls encourages the government to continue defending the currency peg, and this discourages them from attacking it.

\subsection{Recapitulation}

The theoretical literature on speculative attacks analyzes channels through which economic and political variables at home and abroad can provoke crises in foreign exchange markets. It provides a variety of predictions of how economic and political variables should behave in the period leading up to crises. Similarly, theoretical models of depreciation and realignment offer predictions of how exchange rate changes should affect real and nominal variables as a function of structural parameters such as the rigidity of real and nominal wages. There are gaps in the theoretical literature; for example, the decision that a government faces when choosing whether to devalue or float its currency has not yet been tackled. ${ }^{26}$ But the imbalance between theory and evidence in the literature is striking. In contrast to the panoply of theoretical models made available by the economics profession, evidence on the empirical importance of the factors on which theorists focus is partial and conflicting in the case of economic variables and essentially nonexistent in the case of political ones. There is no consensus view on whether speculative attacks are all alike, and

\footnotetext{
${ }^{26}$ We attempt to shed some empirical light on this issue below.
} 
whether different types of speculative attacks resemble one another. In the remainder of this paper we set about rectifying this deficiency.

\section{The Data Set}

Any attempt to systematically study events and crises in foreign exchange markets must start by compiling a list of such episodes. We used the IMF's annual report on Exchange Arrangements and Exchange Restrictions (EAER) to compile a list of officially declared devaluations and revaluations, decisions to float and fix the exchange rate, instances when a fluctuation band was widened, and other significant changes in exchange arrangements. We refer to these as foreign exchange market "events" in contrast to a separate category (introduced below) called exchange market "crises". Crises include unsuccessful speculative attacks and excludes changes in exchange rate arrangements not preceded by or associated with significant exchange market pressure; they overlap with "events". We went through EAER for each year starting in 1959, tabulating and categorizing the events for each country in our sample. The tables at the end of EAER also provide us with binary indicators of the presence of capital controls.

The data appendix provides information on sources we used to construct our macroeconomic variables. Our political variables were constructed from various issues of Keesing's

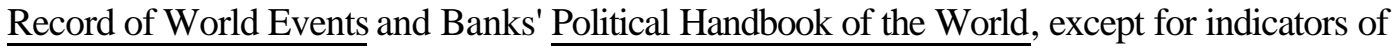
regime strength which were constructed following Roubini and Sachs (1989). ${ }^{27}$

27 Our political variables have many missing observations. 
Any empirical analysis of issues in exchange rate economics requires one to choose the "center" or "reference" country against which the exchange rate and other relative magnitudes are measured. We use Germany (e.g., the exchange rate is defined as the price of a DM). Within the EMS this choice is clear. For the Bretton Woods period, when par values were declared against the dollar, perhaps the U.S. should occupy this position. But the dollar was a weak currency for portions of the 1960s and was subjected to attacks in 1971 and 1973. If the response to attacks is different in strong and weak currency countries because, for example, the costs of lowering interest rates are not the mirror image of the costs of raising them, there is an argument for using a center country with a consistently strong currency. For this reason we use Germany as the reference country throughout. ${ }^{2829}$

Before proceeding, a number of caveats are in order. First, published changes in international reserves are a very imperfect guide to the magnitude of foreign-exchange-market intervention. Monetary authorities sometimes report only the gross foreign assets of the central bank. But since it is standard operating procedure to arrange for stand-by credits in foreign currency, the authorities may intervene by drawing on credit lines without having to sell any of their reported foreign assets. Even countries which provide data on foreign liabilities omit a number of

28 In fact, our results were largely unchanged when we substituted the U.S. for Germany for the pre-1971 period. Further analysis on this topic is warranted.

29 Note that when we cull devaluations, instances when the exchange rate was floated and other foreign exchange market "events" from EAER, we consider the behavior of a currency vis - a-vis the country's chosen peg -- typically the dollar prior to 1971 -- rather than vis-a-vis the center country, Germany. For example, when the Dutch guilder was revalued against the ecu but not against the deutschemark in the second half of the 1980s, we classify this as an event. 
operations which are typically undertaken during periods of speculative pressure, such as offbalance-sheet transactions like swaps and forward market intervention.

Even when published data are accurate, intervention by foreign central banks can be hard to detect. In the ERM, interventions are compulsory at the margins of the currency grid. It is always the case that two (or more) currencies reach their margins simultaneously; thus, compulsory interventions are undertaken simultaneously by two (or more) central banks. Insofar as we analyze changes in the reserves of each country relative to changes in German reserves and Germany is a strong-currency country throughout our sample, we are likely to pick up much of this foreign intervention. But intervention undertaken by third countries will not be detected. This would be the case if the Netherlands intervened to support the Italian lira, for example. There is also the problem of attributing Germany's interventions to a particular country. German intervention in support of the Italian lira could produce a large percentage rise in German reserves relative to those of the Netherlands, seemingly signaling an attack on the guilder in a period when Dutch reserves were rising. Only proprietary central bank data on exchange-market intervention would solve this problem. Reassuringly, work by Weber (1994) shows that the IMF series we use are broadly similar to proprietary intervention data.

In addition, quarterly observations may not be of a sufficiently fine periodicity to identify every speculative attack, especially unsuccessful ones. Pressure against pegged currencies can mount and be repelled through interest-rate increases or foreign-exchange-market intervention within the month. If an attack is launched and repelled in a matter of days, the average behavior of interest 
rates and international reserves over the quarter may not reveal the intensity and frequency of speculative pressures.

Finally, changes in capital controls may affect the meaning of interest differentials and reserve changes. When controls are in place, the authorities may keep the interest rate on the domestic money market virtually unchanged while defending the parity with sterilized purchases on the foreign exchange market. The problems this creates for our analysis could be circumvented through the use of offshore interest rates; in practice, these are available for only a few countries, and even then only recently. An alternative is to use the imperfect data that are available on capital controls to contrast the behavior of interest rates, reserves and other variables in periods when controls were present and absent; we pursue this in Eichengreen, Rose, and Wyplosz (1994b).

\section{The Story in Pictures}

We begin our search for regularities by plotting the data. Figures 1 through 5 show the movements of various macroeconomic variables around different exchange rate "episodes" (we use the term to denote both "events" and "crises"). The five figures portray respectively: devaluations; revaluations; exchange rate flotations; fixings of exchange rates; and other exchange rate regime events (e.g., changes in band width, unification of exchange rates, transitions to crawling pegs and so forth).

Each of the figures contains sixteen panels. Each of these small graphs illustrates the behavior of a single variable for a four-year window around the time of devaluations (in the case of Figure 1), comparing its behavior with that of a control group of country-period observations in 
which no exchange rate episode occurred. These can be thought of as analogues to the event studies used in the corporate finance literature. The top-left panel, for example, shows the behavior of foreign exchange reserves (in annualized percentage changes, relative to Germany), beginning eight quarters before devaluation, continuing through the actual event (marked with a vertical line) and ending eight quarters after devaluation. We show the deviation of this variable from its value during "typical" periods of tranquillity (interludes in which no events or crises occur). ${ }^{3031}$

Average values are plotted in the panels; a band of plus and minus two standard deviations is also provided to illustrate the extent of variation. ${ }^{32}$

\subsection{Realignments}

The patterns in Figure 1 make intuitive sense. Reading across the first row, we see a steady loss of foreign exchange reserves for several quarters prior to devaluations associated with persistent weakness in the external accounts. The dollar value of exports falls in the period leading up to

30 Our control group excludes all observations for both actual events and for observations defined as crises, using the methodology we develop below. We also exclude observations within a twosided one-quarter window of each event and crisis to avoid double-counting.

${ }^{31}$ Although there are 81 (potentially non-independent) devaluations in our sample, the number of observations than underlies an observation in any individual panel may be lower because of missing data. In this sense, the samples are not directly comparable across panels. Making our panels cross-comparable would involve the sacrifice of many observations and much precision. It should be noted that these "devaluations" need not involve a jump in the bilateral DM exchange rate.

32 Our measures are unweighted; one could imagine weighting by country- or devaluation size. Given our positive results for devaluations, and the difficulty of choosing weights for regime transitions, we prefer unweighted data. One could also imagine de-trending the data, removing persistent movements so as to focus attention on innovations. If our observations are independent, then are two-standard deviation bands are approximately $95 \%$ confidence intervals. 
devaluations, by about five per cent (compared to the observations for periods of tranquillity that comprise our control group). Import growth is also higher prior to devaluations than during periods of tranquillity. Unsurprisingly, the current account deficit is about two per cent of GDP higher at devaluations than in periods of tranquillity. ${ }^{33}$

Following devaluation, these patterns are reversed. Reserve losses slow and end after two post-devaluation quarters. Exports recover within a year to typical values; the turnaround in imports and the current account takes longer (perhaps due to the reasons traditionally cited in the literature on the "J-curve").

The second row shows that devaluing countries run larger deficits (as always, relative to Germany) than do countries in the control group, although the two-standard-deviation bands suggest that this differential is barely significant statistically. Domestic credit and money grow faster prior to devaluations than in tranquil periods; those growth-rate differentials decline (at least temporarily) after devaluation, inconsistent with the self-fulfilling attack model..$^{34}$ Thus intervention in support of the exchange rate appears to be sterilized during the run-up to devaluations. The real effective exchange rate is overvalued prior to the devaluation; competitiveness improves with devaluation and stays higher for a couple of years.

The third and fourth rows document the response of domestic markets. The rate of CPI inflation bears the expected relationship to money growth: it is faster, by two or three percentage points per quarter, in countries about to devalue than in the control group. This behavior is

33 Throughout, positive values for the current account and budget balances indicate surpluses. 
mirrored, though to a lesser degree, in the behavior of wage inflation and the long-term bond yield.

Short-term interest rates are higher than in the control group for the two years leading up to devaluation, as if a positive probability is attached to the change in the exchange rate. As the event gets closer and probabilities of devaluation are refined, the interest rate rises significantly in anticipation of the coming devaluation. ${ }^{35}$ Stock prices are significantly lower in the period leading up to devaluation, presumably reflecting these higher interest rates. Neither short nor long interest rates decline substantially afterwards. This suggests that devaluation has credibility costs, and that markets expect further subsequent attacks. ${ }^{36}$ Devaluation is good for expectations of profitability: stock prices rise in the wake of the event. Since prices rise significantly faster than wages, a decline in the real wage may be the source for the expected profitability implicit in higher stock prices.

The final row looks at the labor market and output. Unemployment is higher in the years surrounding devaluations even though real wages are falling. Following the parity change, employment and output growth slow down quite markedly after a year and a half.

Overall, these patterns suggest that countries devalue mostly in response to external imbalances (falling reserves, current account imbalances, poor competitiveness and so forth), though there are also internal imbalances (high unemployment). The external imbalances are associated with

${ }^{34}$ Although we only show M1, the behavior of M2 turns out to be similar.

35 This reasoning relies on both uncovered interest parity and an absence of mean-reversion when the exchange rate is constrained within a band; however, both of these are questionable assumptions.

${ }^{36}$ This is especially plausible if the "interest rate defense" imposes costs per se through e.g., more politically painful unemployment, as suggested by Bensaid and Jeanne (1994). The "contagion effect" is the spread of such attacks across countries as well as across time; we explore this further below. 
expansionary monetary policies, although the roots of monetary expansion do not obviously lie in the fiscal domain. Governments appear to react well to devaluations, tightening monetary and fiscal policies in order to lock in competitiveness gains. Succinctly, devaluations appear to be caused for traditional reasons and appear to work. ${ }^{37}$

While macroeconomic variables can be useful for predicting which countries are most likely to devalue, they are less useful for predicting the precise timing of the event (which has been the focus of much of the theoretical literature). Still, there are only a few sharply defined dynamic patterns in the run-up to devaluations. For instance, while the unemployment rate is a percentage point higher around devaluations, the differential does not change significantly during the years prior to the event.

Figure 2 is the analogue to Figure 1 for the case of revaluations (scales vary across figures). Most patterns mirror images of Figure 1. The growth of foreign exchange reserves is faster prior to revaluations than in the control group and no different afterwards. Exports grow faster and imports more slowly prior to revaluations, (though not afterwards); this is mirrored in the behavior of the current account. There is little evidence that the reason why countries have strong external accounts in the period leading up to revaluation is that monetary and fiscal policies are tight. Money and credit growth, wage and price inflation, and short- and long-term interest rates tend to be lower in the revaluing countries than in periods of tranquillity. Like devaluations, revaluations have mainly external causes and effects; domestic variables tend to behave unexceptionally.

${ }^{37}$ It is even more surprising that such an old -fashioned sticky-price model works well for devaluations, given the varying sizes of the devaluations, some of which were undertaken for political reasons (especially the multilateral EMS realignments). 
To summarize, devaluations typically occur when unemployment is high, monetary policy is loose, inflation is rapid, and the external accounts are weak. Late attempts to moderate monetary policy precede but do not preclude devaluations. Once the devaluation has occurred, reserves flow back, and external balance is restored while monetary and fiscal policy tighten. In the case of revaluations, macroeconomic variables move in the opposite direction, but their movements are less dramatic. Broadly speaking, exchange rate realignments are all alike.

\subsection{Regime Transitions}

Figures 3, 4, and 5 portray the movements of our variables around three different sorts of regime transitions: instances where the exchange rate was floated, when it was fixed, and other transitions (such as exchange rate unifications, changes to band-widths, and so forth).

Conventional wisdom is that fixed exchange rates are floated in response to weakness. One thinks of the ignominious departures of the Pound and Lira from the EMS in September 1992, and Sweden's abandonment of its unilateral peg two months later. It is also true, however, that the yen, guilder, and the deutschemark were floated out of the Bretton Woods System in response to strength.

Unfortunately, the data speak quietly. Some of the movements around flotations in Figure 3 seem sensible. For instance, reserves fall quickly (compared with periods of tranquillity) prior to flotations. But other movements are more difficult to interpret, such as the strong current account and below average long-term interest rates. Perhaps the most striking feature of the figure is that most of the confidence intervals overlap the zero line, implying that the flotations cannot be distinguished from tranquil periods at standard conventional levels. Flotations are idiosyncratic, with 
few typical co-movements characterizing either the run-up to or the aftermath of flotations. There are signs that policy is relaxed after flotations; money growth stays higher than that in tranquil times, while wage and price inflation picks up. Further, the real economy improves, as unemployment falls while output and employment growth rise. But these effects need not be caused by any slackening of policy; a flotation-induced depreciation can be expected to be inflationary and to improve competitiveness. But the long-term interest rate does not rise in anticipation of an inflationary binge, despite the inevitable loss of credibility. Although the movement is quite weak, there is a deterioration of the budget.

Our negative result can be explained in a number of different ways. It may be that countries float their exchange rates for very different reasons, despite the common impression that countries are forced to float out of weakness. ${ }^{38}$ Also, countries switch from a policy of fixed exchange rates towards alternatives which may differ enormously, making the post-flotation heterogeneity perhaps unsurprising. ${ }^{39}$ But it is similarly difficult to generalize about the macroeconomic causes and consequences of decisions to fix a previously floating rate (or to widen the band or otherwise change the exchange rate regime).

Fixing might be though of as the final step of a process of policy discipline, the crowning of disinflation efforts. Indeed, over the two years preceding a fixing, we observe some evidence of

\footnotetext{
${ }^{38}$ Our result is not an artifact of our choice of Germany as the base country; similar results hold if treat the United States as the base country before 1973, and Germany thereafter. This is perhaps to be expected, since the United States was commonly viewed as a "weak center" during the collapse of Bretton Woods, whereas Germany was a "strong center" during the EMS speculative attacks of 1992-93.
}

${ }^{39}$ We thank Torsten Persson for this point. 
declining wage and price inflation. Yet fixings are also preceded by reserve losses and unremarkable fiscal and monetary policy. Confidence intervals are wide, and few regularities distinguish either the runup to regime transitions or the periods immediately following them. While realignments seem to be fundamentally alike, transitions between exchange rate regimes are unpredictable and idiosyncratic.

Two conclusions follow. First, many regime transitions do not appear to be warranted by macroeconomic imbalances of the sort one expects to find. Second, the speculative attacks that provoke them are not clearly justified by subsequent changes in the stance of policy. ${ }^{40}$

It may be that our 33 flotations and fixings do not provide a sufficiently large sample to allow the data to discriminate between such events and tranquillity, especially since some of these events are clearly linked and therefore do not provide independent observations (e.g., the flotations of the lira and the pound in September 1992). ${ }^{41}$ Alternatively, different transitions between exchange rate regimes may simply be undertaken for fundamentally different reasons. Markets seem to focus on different aspects of economic and political stability during different speculative attacks. ${ }^{42}$

\subsection{Exchange Rate Crises}

40 There is a certain symmetry in this result. Flood and Rose (1993) show that "fundamentals" (dictated by different monetary models) do not vary across exchange rate regimes; here we show that they do not vary between regime transitions and tranquillity.

${ }^{41}$ It is also important to recall that our regime transitions, like realignments are not necessarily declared in $E A E R$ with respect to the DM.

42 This seems prima facie reasonable; we think recently of British mortgage rates and Italian government debt in September 1992, Swedish financial woes in November 1992, and French unemployment rates in August 1993. 
The preceding evidence is only indirectly informative about the causes and consequences of speculative attacks, since not all speculative attacks on exchange rates culminate in devaluations, revaluations or decisions to float, fix or widen the band. The currency may be supported by the expenditure of reserves by the central bank or by intervention by its foreign counterparts.

Alternatively, the authorities may discourage bear speculation by raising interest rates and adopting other policies of austerity. Nor are all decisions to devalue or float the exchange rate necessarily preceded by speculative attacks. "Events" and "crises" in the foreign exchange market, in our terminology, are not the same. The next step is therefore to identify exchange market crises and to provide an analysis that parallels our event analysis.

\subsubsection{Identifying Crises}

A speculative attack is a period of extreme pressure in the foreign exchange market. Ideally, a measure of this pressure should stem from a model of exchange rate determination (from which the policy actions needed to maintain the currency peg could also be derived). However, much research has underscored the inadequacy of models linking macroeconomic variables to the exchange rate (Meese and Rogoff 1983 is the classic reference). To approach this question, we therefore use a simple, if admittedly ad hoc, method to measure exchange market pressure, following earlier work by Girton and Roper (1977). Speculative pressure is measured as a weighted average of exchange rate changes, interest rate changes, and reserve changes, where all variables are measured relative to those prevailing in Germany, the reference country. Speculative attacks -- crises -- are defined as periods when this speculative pressure index reaches extreme values. Intuitively, an attack on a currency can lead to a loss of reserves, be rebuffed by a rise in 
domestic interest rates (and an associated contraction of domestic credit), or be accommodated by a depreciation or devaluation of the exchange rate. "Events" which entail large fluctuations in quarterly values will be picked up by our index. But not all events entail crises (e.g., orderly realignments), and not all crises are events (e.g., successful defenses) ${ }^{43}$

The question is how to weigh the three components of the index of speculative pressure. As noted above, the empirical literature provides little guidance. An unweighted average has the advantage of simplicity. But a look at the data reveals that the conditional volatility of percentage changes in reserves is several times the conditional volatility of the percentage change in the exchange rate, which is itself several times the percentage change in the interest differential. Movements in an unweighted average will therefore be heavily driven by reserve movements. An alternative is to weight the three components so that their conditional volatilities are equal. ${ }^{44}$ This is the measure on which we focus below. ${ }^{45}$

We refer to those quarters in which our index of speculative pressure was at least two standard deviations above the mean as an exchange market crisis. Sometimes two (or more) potential crises occur close together. To avoid counting the same crisis twice (or more), we exclude

${ }^{43}$ Further, not all speculative attacks may be picked up by our measure of crises. For example, an attack countered successfully by a very brief "interest rate defense" (in which domestic interest rates are raised for a brief period of time) may not be captured.

44 In our benchmark base of equal volatilities, we add the percentage change in relative reserves to 7.5 times the percentage change in the exchange rate and 51.9 times the change in the interest differential.

45 In Eichengreen, Rose and Wyplosz (1994a) we conducted sensitivity analysis in order to gauge how much difference different weighting schemes make. There we found that our central 
second (and subsequent) observations which occur within given proximity to the first crisis. Our initial window width is plus and minus two quarters.

Figure 6 shows the number of crises (and events) over time. Following the relatively placid 1960s, there is an up-tick in events in 1967, when the pound sterling was devalued. The number of crises stays up, reflecting turbulence in the market for other European currencies such as the French franc. The crisis in the Bretton Woods System in 1971 accounts for the peak in the number of events we pick up in that year, but it is notable that we detect only a slight up-tick in the number of crises (which can be interpreted as the crisis of 1971 being essentially a dollar crisis). 1973, in contrast, shows up as a more general crisis. The 1970s are characterized by more crises and events than the 1960s, although they settle down as the decade draws to a close. There are then simultaneous upswings in crises and events after 1980 (associated with global recession, the Volcker-Thatcher disinflations, and the earlier trials and tribulations of the European Monetary System), after 1985 (associated with the high dollar and the Plaza and Louvre Accords designed to bring it down), and after 1991 (associated with the crisis in the EMS). This clustering of crises (and events) is consistent with theories of speculative attacks and policy responses that entertain the possibility of contagious spillovers across countries.

\subsection{2. $\underline{\text { Regularities }}$}

We now analyze the behavior of macroeconomic variables around the crises identified using this technique. Ineluctably, more confidence can be attached to the preceding analysis of "events"

conclusions were largely robust to our choice of weighting scheme. We also found that our procedure picks up an intuitively reasonable sample of speculative attacks. 
than to the analysis of "crises" that follows. Events are based on concrete reports of actual policy measures. In measuring "crises," in contrast, we are forced to construct an index by imposing a variety of assumptions.

Figure 7 shows the evolution of the major macroeconomic variables in the eight quarters preceding and following crises; it is an analogue to Figures 1-5. There is an obvious temptation to compare crises (Figure 7) with devaluations (Figure 1) to see how much difference the categorization makes. While the patterns are similar, they are weaker in the case of crises. (Given our definition of crises, it is no surprise that reserve losses, interest rate hikes and real depreciations are more pronounced around speculative attacks.)

Current accounts weaken prior to crises, like devaluations (though the deterioration is more pronounced). Exports are again weaker, although only for one pre-crisis quarter, and in addition imports rise. Rates of money and credit growth and the rate of increase of wages and prices are faster prior to crises, as prior to devaluations, but again there is little evidence linking this money growth to budget deficits. ${ }^{46}$ Compared to devaluations, monetary policy tightens later and less forcefully. Interestingly, in the run up to the crisis (as with devaluations), the growth rate of M1 decelerates as reserves flow out, suggesting that foreign exchange market interventions are not fully sterilized.

46 The policy stance is more plausibly linked to relatively high unemployment, which is again evident. Curiously, employment growth is also faster in the period leading up to crises. 
Interest rates rise even more sharply at speculative attacks than at devaluations, though they remain high following both. Clearly, both events are unanticipated to some extent. ${ }^{47}$ Long rates are persistently higher prior to crises than in the control group cases, but the differential is insignificant until the crisis quarter itself. (This may be a reflection of the high and rising wage and price inflation and relatively fast employment and output growth.) It would appear that there is le ss of a market consensus about the timing of crises than about the timing of devaluations. To put it another way, crises are more difficult to predict than devaluations. ${ }^{48}$

We next try to shed light on the distinction between crises and events by splitting our sample of crises into successful attacks and successful defenses. We define the former as a crisis followed within a year by an event (e.g., a devaluation or flotation). Figure 8 provides a comparison between the two. It is an analogue to Figure 7 but compares successful attacks to successful defenses instead of comparing all crises to periods of tranquillity.

There is no clear way of telling what makes attacks succeed or fail; most macroeconomic variables exhibit the same behavior before successful and failed attacks. One difference is that the growth of output and employment is slower and unemployment higher before successful attacks. External conditions do not vary substantially between successful and unsuccessful attacks; imports, and the current account are not significantly different between the two, even though exports, curiously, are stronger in the case of successful attacks in spite of significant overvaluation of the

47 Rose and Svensson (1994) provide a similar insight for the period preceding the 1992 EMS crisis; interest differentials rose only immediately before the crisis, and some of the 1992 attacks were not successful.

48 Alternatively, this may be an indication that our technique for measuring crises is imperfect. 
exchange rate which is corrected by the attack itself. Perhaps the single most promising variable to tell successful attacks and defenses apart is the fiscal situation. Countries whose currencies are successfully attacked have larger and worsening budget deficits before attacks, although this does not show up in the monetary aggregates. Interest rates and the budgetary position improve dramatically after the event, while money growth falls, as if the authorities learn their lesson and strive to improve credibility. Thus, there is little evidence that speculative attacks, whether self-fulfilling or not, typically prompt governments to ease fiscal and monetary policies. However, this does not prevent a general wage and price inflation which is reflected in long-term interest rates. Successful attacks also take place in the context of a significantly weaker economy than successful defenses (as is to expected from the generally weak fiscal positions). Unemployment rates are higher and employment and output growth are lower before attacks that succeed. After successful attacks, a number of macroeconomic indicators improve sharply, including the budget, exports and foreign exchange reserves.

All this suggests that governments are less able to defend themselves against speculative pressures during cyclical contractions than expansions, consistent with models like OzkanSutherland (1994) and Bensaid-Jeanne (1994) in which the government balances the exchange rate constraint against output and employment objectives.

These results do not provide much hope for identifying early signs of impending problems. The problems are threefold. First, the ex ante differences between successful attacks and successful defenses are generally domestic, whereas devaluations seem generally to be provoked by 
international imbalances. Second, differences are almost always statistically and economically insignificant, and move sluggishly over time (thereby giving few indications about the timing of speculative attacks). Third, while the obvious place to look for signs of difficulties is financial markets, short- and long-term interest rates appear to be ex ante indistinguishable, not only between successful and unsuccessful attacks, but also between exchange rate crises and events and periods of tranquillity.

\subsection{Sensitivity Analysis}

We establish the robustness of our findings by briefly examining a variety of perturbations to our methodology. Our findings are not appear very sensitive.

Our most important check consisted of dropping all non-ERM observations from our data

set. One advantage is that the remaining observations correspond to more homogeneous and recent conditions for a group of countries with exchange rates limited to relatively narrow bands. This essentially limits our event analysis to devaluations, and has the additional advantage of excluding all floaters from the sample.

Figure 9 closely resembles its analogue, Figure 1. Consistent with the standard view of EMS realignments, ERM devaluations were preceded by generally weak external positions: falling reserves, weak exports, high import growth and current account deficits. Government budgets show larger deficits than in those of tranquil countries; money and credit growth is similarly high. These expansionary policies are reflected in higher actual and expected inflation, high long-term interest rates and depressed stock prices. The devaluations are partially expected, though interest 
rates rise sharply close to the actual realignments. Further, realignments tend to take place in a weak internal environment of high unemployment and low employment growth.

Movements after the devaluations are also consistent with wisdom. Monetary and fiscal policies appear to be tightened slowly after realignments, although both short- and long-term interest rate differentials persist in the face of imperfect credibility. Wage and price inflation gradually fall, and there is little effect on the real economy. The authorities are rewarded for these actions with a booming stock market and reserve inflows. Thus realignments appear to have had the intended effects of improving external positions.

We also undertook a number of additional sensitivity analyses. For instance, we split our sample in different ways. We also normalized the data displayed in our graphics differently, comparing our variables around exchange rate events and crises (as always in differentials vis-a-vis Germany) to country-specific periods of tranquillity rather than to periods of tranquillity drawn from the sample as a whole. We experimented with removing observations within a two-year window around exchange rate events, so as to avoid counting the same exchange rate episode twice, and two-quarter windows around periods of tranquillity. None of these perturbations substantially changed the results.

Finally, we provide some evidence on the importance of capital controls. We divide our exchange rate episodes into those which were experienced with and without capital controls (as measured by the dummy variable in EAER). Figure 10 provides the evidence; it is the analogue to Figure 7, but compares exchange rate crises during periods without capital controls to crises 
experienced during periods with controls, not all crises to tranquillity. (It turns out that we only have enough observations both with and without capital controls to compare exchange rate crises.)

When capital is more mobile, money growth, long-term interest rates and price and wage inflation are lower before crises. Controls allow the authorities to bottle up more inflation before an attack is provoked. There is also significantly higher employment growth before crises when capital is unconstrained. While many of the differences are statistically insignificant, this does confirm our previous work (Eichengreen, Rose and Wyplosz 1994b) which shows that controls both allow more lax macroeconomic policy and increase the incidence of (more manageable) attacks.

\subsection{Recapitulation}

Countries which devalue experience problems of external balance in the period leading up to the event. Their trade deficits and reserve losses are associated with relatively expansionary monetary policies. In addition, the period leading up to devaluations is characterized by problems of internal balance as reflected in relatively high levels of unemployment; the expansionary monetary stance may be partly motivated by these domestic problems. Revaluations are generally the mirror images of devaluations and still more by the fact that crises resemble actual devaluations.

However, evidence of systematic patterns surrounding other events in foreign exchange markets paints a very different picture. In contrast to realignments of fixed exchange rates, transitions between exchange rate regimes seem both unpredictable and idiosyncratic. While devaluations are fairly predictable in other words, events like flotations are not. Since it is not known ex ante how a government will react to any given speculative attack, our findings do not bode well for the development of "early warning" systems designed to detect pending problems in 
international financial markets. They are also consistent with the belief that many changes in exchange rate regimes are caused by attacks which, while being successful, are not warranted by sinful policies either before the transition or after.

\section{Statistical Analysis}

The presentation in section 4 relies upon graphical tools. Using the theoretical framework presented in section 2, we examined a number of macroeconomic variables to search for patterns in the periods surrounding exchange rate events and crises. Nevertheless, this approach is intrinsically informal. In this section, we consider more rigorous statistical tests of the generalizations developed in section 4.

We undertake two types of statistical analysis. First, we introduce political variables and check to see if they are closely related to event and crises. Second, we replace the variable by variable approach with an analysis of the joint effects of the economic and political variables of interest (by estimating multivariate regression models).

\subsection{The Role of Politics}

Table I presents information on a variety of different political variables for our taxonomy of exchange rate episodes. We break our sample into seven columns corresponding to mutually exclusive and jointly exhaustive partitions. These are: devaluations; revaluations; exchange rate flotations; fixings of exchange rates; other changes in exchange rate regime (such as changes in band widths); failed attacks (crises which do not coincide with one of the five events); and the complimentary sample, which we think of as being "tranquillity". 
The rows provide tabulations of our variables across these episodes. We are searching for signs that political events are not randomly distributed across exchange rate episodes; for instance, that governments tend to fall disproportionately before or after realignments. This is done by testing the hypothesis that a given political variable has no effect. The table is interpreted as follows: a high value of the test statistic means that we can reject the hypothesis that the relevant political variable exhibits the same pattern across exchange rate episodes (we show the value of the chi square statistics along with the degrees of freedom; two asterisks denote significance at the .01 level).

By and large political phenomena are rarely linked to exchange rate episodes. Our first row shows that the political orientation of the government seems to be independent of exchange rate episodes. ${ }^{49}$ The same is true of both elections and changes in government (which do not require elections in many systems), so that political uncertainty per se does not seem to provoke attacks.

It is perhaps unsurprising that government victories (e.g., winning an election) are not strongly associated with speculative attacks (though one might have expected disproportionate numbers of tranquil periods). This is true not only of contemporaneous government victories but also of those which occurred during the past or next year. But a defeat of the government in the past year is associated with a disproportionately larger number of realignments; a new finance minister in the past year has the same effect. On the other hand, there is little evidence that exchange rate episodes are associated with future government defeats; the finance minister is used as a sacrificial lamb (consistent with Cooper's celebrated result).

49 On reflection, this seems unsurprising, since opposition parties frequently state that they will not change the exchange rate regime, often for fear of being blamed for precipitating a speculative attack. 
Table I also confirms the importance of capital controls (as measured by the EAER dummy variable). Periods of tranquillity and capital mobility out-number periods of tranquillity with controls by about two to one. But important events like devaluations and flotations are more likely to occur without controls, and failed attacks are more likely when controls are present. It seems that controls allow governments to avoid not only realignments (which are frequently warranted by economic circumstances) but also regime transitions. Capital controls may be a potent weapon for governments wishing to avoid (frequently unjustified) regime switches, in other words.

\subsection{The Joint Effects of Economic and PoliticalVariables}

Most of the preceding analysis can be criticized on two grounds. First, it is univariate; we compare the behavior of our variables, one by one, during e.g., devaluations and periods of tranquillity. We do not consider groups of variables and ask whether their joint behavior differs between crises or events and tranquillity. Second, it is uninomial. We compare each exchange rate episode state (crisis, devaluation, revaluation, flotation, etc.) to periods of tranquillity in isolation from one another. We do not analyze the causes and consequences of crises and various events simultaneously. It is well known, however, that such a piece-meal approach may lead to unwarranted conclusions. That is why we now use a technique to rectify these deficiencies. Our econometric strategy has four important features. The model we develop is multivariate in that it considers a number of economic and political variables simultaneously. It is multinomial in that it simultaneously compares periods of tranquillity to crises and a variety of different "events." It is dynamic in that it examines periods of time both before and after crises and events. We look 
backward to study the antecedents of various exchange rate episodes, and forward to examine their consequences. Finally, it is non-structural in that it does not estimate or test any particular speculative attack theory. Rather than confirming or rejecting a narrowly defined structural model, our statistical approach amounts to systematic data exploration.

We proceed as follows. We ask whether the economic and political variables under consideration can help predict the likelihood of each of the events listed in the top row of Table I: a crisis which is not an event (a failed attack or successful defense), devaluation, revaluation, flotation of the exchange rate, fixing the rate, other events in foreign exchange markets, and tranquillity (the omitted alternative). We use a one quarter exclusion window so that each country contributes no more than two observations annually, in order to avoid counting the same episode twice. In assessing the role of each variable, we consider both its past and future linkages to the exchange rate episode (we estimate a multinominal logit model). ${ }^{50}$

We began by using (the leads and lags of) nearly all of the variables discussed above but found that (fourth-order moving) averages are appropriate for analyzing the causes of crises and

50 In order to deal with the well-known small-sample problems of multinomial logit estimation we need to reduce the number of regressors (sixteen macroeconomic variables alone are show in most of the figures!). One way around the problem is to estimate a tightly parameterized theoretical model which would make few demands on the available data. (As discussed above, this is the tactic adopted by the small existing literature, e.g., Blanco and Garber (1986)). The problem is that poor estimates would then constitute rejection of a single model, when we are more interested in developing a stylized picture of different exchange rate episodes. Our approach is to save degrees of freedom by representing leads and lags of regressors us ing moving averages in a reduced form. Thus, instead of including separately the first, second, third and fourth lags of e.g., inflation differentials in our regressions, we include only a single term which is the average inflation differential in the preceding year. All models are estimated using maximum likelihood. 
events. Very similar results are found when we utilize second - or eighth-order lags. This is unsurprising given the smooth behavior of the variables manifest in the figures.

Table II collects the results. We show how much each economic or political variable listed in the first column affects the probability that the event listed in the top row will occur. A positive number indicates that the relevant variable raises the probability of the event, and conversely for a negative sign. The numbers in parentheses show the probability that the effect is nil; a low value indicates that the measured effect is not a statistical fluke, so that the variable does affect the event under consideration. ${ }^{51}$

At the bottom of Table II we report a number of summary tests. The first series ask whether events listed in the top row differ (in the sense that the behavior of the economic and political variables listed in the first column is not the same) from the benchmark case of tranquillity. A high value of the chi-square statistic indicates that the answer is positive, and the number in brackets indicates the probability. For example, there is zero probability that failed attacks are identical to tranquillity. The results broadly confirm the discussion above which is based upon graphics.

Failed attacks (a subset of the crises portrayed in Figure 6) and devaluations are significantly different from periods of tranquillity. Revaluations are not, as seems reasonable given the small

51 The interpretation of individual coefficients is blurred for two reasons. First, coefficient interpretation in multinomial logit is always slightly tricky. Second, the non-structural nature of our estimation means that each coefficient represents the partial effect of the regressor on the likelihood of the cell's occurring instead of tranquillity, that is, holding all other effects constant. But the comovements we observed earlier around realignments may make partial correlation coefficients uninteresting. 
number of revaluations. More importantly, neither exchange rate flotations nor other changes in regime can be distinguished from periods of tranquillity, a reflection of the fact that regime transitions seem idiosyncratic. Exchange rate fixings can be distinguished from periods of tranquillity, but this is mostly the result of the fact that collective systems of managed rates like the EMS begin at the same time.

The second series of test ask the opposite question: do the economic and political variables behave differently across the different episodes under consideration? We look separately at lagged and leading effects. These statistics can be interpreted like the first set. Thus the hypothesis that lagged government victories are irrelevant for all cells cannot be rejected, unlike the hypothesis that lagged government defeats are irrelevant. The variables that matter are capital controls (both lags and leads), past government defeats, past and future inflation, future GDP and employment growth and past current account balances.

Overall, what do we find in the details of the table? In a word, confirmation of the portrait painted by our more informal analysis of the data. Past crises and events matter for current ones: this is an indication that credibility is an important factor. Past crises make failed attacks more likely, while recent events make exchange rate fixings much more likely. Capital controls are also highly significant, as expected. Their presence makes future devaluations less likely, and future unsuccessful attacks more likely. Capital controls are also more likely to appear after devaluations and to disappear after a failed attack.

Although recent government defeats seem to provoke realignments, there is remarkably little evidence of feedback between the government's popularity and the exchange rate regime. The role 
of monetary factors and inflation in triggering attacks is confirmed. In contrast, fiscal laxity does not play an important role. Put differently, bond-financed budget deficits typically do no pose an exchange rate problem, unless they have an inflationary impact. The role of labor market conditions is generally not confirmed, however, although favorable employment growth raises the probability of a successful attack. A deteriorating current account balance makes devaluation more likely.

The interpretations of leads of variables can be tricky. One possible reading of the table, for example, is that a successful defense is followed by faster output growth. But the results of Table II are also compatible with the view that success in repelling an attack is enhanced by the expectation that the economy is turning around and about to grow faster. In the discus sion which follows, we freely use intuition to in terpret the results, keeping in mind this ambiguity.

A devaluation is followed by budgetary relaxation and an improvement in the current account, which suggests that private spending declines. Fixing the exchange rate is rewarded with a significantly higher growth rate. Similarly a successful defense is conducive to growth, and is also followed by inflation; the same applies to fixings.

There is also much to learn from the insignificant entries in Table II. Unemployment rates, government budgets, and the growth rate of domestic credit are essentially unrelated to exchange rate episodes. The latter two are especially important, since they represent the tools of monetary and fiscal policy whose laxity is said to both provoke and be provoked by devaluations, exchange rate flotations and the like. ${ }^{52}$

52 We also estimated ad hoc refinements of these models to focus attention on two phenomena of interest. First, the basic "fundamentals based" speculative attack model focuses attention on two underlying causes of speculative attacks: government budget deficits and credit growth in excess of 


\section{Policy Implications}

The greater the strains on the international monetary system, the louder grow calls for international monetary reform. Our analysis certainly does not suggest that this concern is misplaced. It confirms that the exchange rate can be very important for macroeconomic outcomes. We show, for example, that realignments are frequently taken in response to imbalances in macroeconomic fundamentals. These actions can have important corrective effects, notably in redressing imbalances in the external accounts that might otherwise undermine a government's economic policy strategy. But while there is some evidence that attacks are preceded by relatively rapid growth of money and credit and high inflation, there is considerable heterogeneity across episodes; it is difficult to detect a pattern of highly significant differences between attacks and tranquil periods. And, revealingly, there are few significant differences in the behavior of these variables when we divide crises into successful and unsuccessful attacks. While some attacks are plausibly motivated by imbalances in fundamentals, others are not. And there is no obvious difference in which type of attacks succeed or in their post-attack effects.

More importantly, we show that changes in exchange rate regime, as opposed to realignments, are not strongly and systematically linked to fundamentals. This is true of the

income growth. We estimated models which omit other regressors so as to try to isolate these effects. But it is not the case that lags of either factor are substantially more noticeable in a more parsimonious model. Second, we searched for systematic changes in the same regressors before and after actual exchange rate events, in an attempt to identify the policy switches indicated by the "self-fulfilling" speculative attack model. We met with a similar lack of success, further confirming our view that there do not seem to be policy switches after exchange rate episodes. 
antecedents of flotations, fixings and band - width changes, and also true of their aftermath. Many regime switches appear to be unwarranted by macroeconomic imbalances, and they do not deliver obvious changes in macroeconomic policy.

Our results are consistent with a world in which some speculative attacks on currencies -and some preemptive realignments taken by governments to head off attacks -- are prompted by a history of inappropriate economic policies that give rise to overt imbalances in macroeconomic fundamentals, but in which other attacks are not grounded in fundamentals and are of the selffulfilling variety (even though few changes in macroeconomic policy are subsequently observed!). This suggests that governments following policies that are in theory consistent with the indefinite maintenance of their exchange rate target may nevertheless come under speculative pressure. When and where attacks erupt -- and when and where they succeed -- remain difficult to predict.

These findings reinforce skepticism about the viability of several otherwise attractive proposals for international monetary reform. Advocates of exchange rate target zones (Williamson and Henning 1994; Bergsten 1994) argue that, if governments only commit to the pursuit of the "right" policies, exchange rates between the currencies of the leading industrial countries can be held within bilateral fluctuation bands of, say, plus or minus ten per cent, which would represent a considerable improvement over the historical volatility of the dollar-yen and dollar-deutschemark rates. Our results suggest that pursuit of any particular set of policies is no guarantee of insulation from speculative pressure, and indeed no guarantee that an attack, once launched, will not succeed. They suggest that recommendations of a return to even narrower bands, whether globally (Bretton Woods Commission 1994) or in Europe, where EMS bands were widened from 2 1/4 to 15 per 
cent in 1993, are more problematic still. The realignment mechanism seems to work well, in that devaluations are both warranted and effective, while not tempting the authorities towards lax policies. However, systems of pegged but adjustable rates (or bands) are inherently fragile in that they disintegrate quickly under stress, even when the speculative pressures giving rise to the crisis are not obviously grounded in fundamentals.

This conclusion leaves only a limited menu of options for improving the operation of the exchange-rate system: (1) monetary union a la Maastricht, which promises to abolish exchange rate instability by abolishing the exchange rate; (2) a transactions tax on foreign currency dealing to provide policymakers insulation from market pressures; and (3) learning to live with the dirty float. All of these options have drawbacks. A single world currency, or a single currency for the OECD countries, hardly seems feasible in our lifetimes. As our own analysis of devaluation shows, the exchange rate can be a useful instrument of adjustment. And the greater the asymmetry in the disturbances affecting the different OECD countries, the stronger the argument for retaining the exchange-rate escape clause. Who is to say that the OECD as a whole, or even just Europe, the U.S. and Japan, comprises an optimum currency area?

Moreover, as the debate over Maastricht illustrates, monetary unification raises fundamental political questions about the limits of national sovereignty. Will countries really be prepared to forsake their monetary sovereignty once and for all? Will they require political integration -- some form of world government in effect -- as a precondition? Europe, with 50 years of experience, has proceeded sufficiently far down this road that EMU remains possible by the end of the century. But 
it is hard to imagine a monetary union between, say, the EU and the United States over a horizon relevant for practical policy discussion.

Monetary unification at the regional level can still be useful for resolving exchange rate dilemmas. By eliminating intra-European exchange rate instability, EMU can go a long way toward insulating European countries from exchange-rate-related disturbances. Such insulation is not complete, since as recent experience demonstrates the ecu could still fluctuate against the dollar and the yen. But European countries trade and invest mainly in other European countries; hence EMU would help to insulate the bulk of Europe's international transactions. A North American monetary union could have many of the same benefits for Canada, Mexico and the United States, although those countries remain fifty years behind Europe in their pursuit of monetary integration. ${ }^{53}$ But monetary unification at the regional level will solve problems of exchange rate instability only if intraregional instability is not simply transformed into inter-regional instability. Of this there is no guarantee.

The second option is a Tobin tax on foreign exchange transactions. ${ }^{54}$ If effective, this would enhance policymakers' ability to contain market pressures, allow them to repel self-fulfilling attacks, and provide the breathing space needed to organize orderly realignments. A system of target zones, crawling bands or pegged-but-adjustable rates would be considerably easier to operate.

Economists, including the authors of this paper, resist the idea of interfering in the operation of

53 Whether regional monetary integration offers a solution to Japan is more dubious, since Japan trades and invests heavily not just in Asia but in the United States. See Bayoumi and Eichengreen (1994).

${ }^{54}$ See Eichengreen, Tobin and Wyplosz (1995), from which the following discussion is drawn. 
markets. The relevant question, however, is whether the costs of such interference are justified if they deliver the benefits of greater exchange rate stability.

Then there is the problem of evasion. To be effective, a foreign exchange transactions tax would have to be implemented globally. It would have to apply to all jurisdictions, and the rate would have to be equalized across markets. Were it imposed unilaterally by one country, that country's foreign exchange market would simply move offshore. Thus, the policy would have to be universal. Its implementation and coordination would have to be the responsibility of a multilateral agency like the International Monetary Fund, which would have to possess enforcement capabilities. The IMF might be authorized to set the size of the tax within limits. It would have to possess sanctions to be levied on countries that fail to comply with the measure. An initiative with these characteristics would presumably have to take the form of an amendment to the IMF Articles of Agreement. This is not something that will occur overnight.

For those who oppose both monetary unification and the Tobin tax, there remains only one alternative: living with floating -- misalignments, volatility and all. This means more systematically adapting domestic policies in a manner consistent with exchange rate stability, coordinating policies internationally, and hoping for the best. There are no facile alternatives free of costs. We say this in order to focus the attention of critics of the existing system of floating exchange rates on the hard choices they must confront. 


\section{References}

Alesina, Alberto and Guido Tabellini (1989), "External Debt, Capital Flight and Political Risk," Journal of International Economics 27, pp.199-220.

Bank for International Settlements (1993), 63rd Annual Report, Basle: BIS.

Banks, Arthur S. (various years), Political Handbook of the World, Binghamton, NY: CSA publications.

Barnett, Richard C. and Mun S. Ho (1995), "Sunspots, Currency Substitution and Inflationary Finance," unpublished manuscript, SUNY-Buffalo and Kennedy School of Government, Harvard University.

Barro, Robert and David Gordon (1983), "Rules, Discretion and Reputation in a Model of Monetary Policy," Journal of Monetary Economics 12, pp.101-122.

Bayoumi, Tamim and Barry Eichengreen (1994), "One Money or Many? Analyzing the Prospects for Monetary Unification in Various Parts of the World," Princeton Studies in International Finance No. 76 (September).

Bensaid, Bernard and Olivier Jeanne (1994), "The Instability of Monetary Policy Rules," unpublished manuscript, University of Paris I.

Bergsten, C. Fred (1994a), "The Rationale for a Rosy View: What a Global Economy Will Look Like," The Economist 328 (September, pp.57-59.

Bergsten, C. Fred (1994b), "Managing the World Economy of the Future," in Peter B. Kenen (ed.), Managing the World Economy Fifty Years After Bretton Woods, Washington, D.C.: Institute for International Economics, pp.341-376.

Blanco, Herminio and Peter M. Garber (1986), "Recurrent Devaluation and Speculative Attacks on the Mexican Peso," Journal of Political Economy 94, pp.148-166.

Bretton Woods Commission (1994), Bretton Woods: Looking to the Future, Washington, D.C.: Bretton Woods Commission.

Budd, Christopher, Christopher Harris and John Vickers (1993), "A Model of the Evolution of Duopoly: Does the Asymmetry between Firms Tend to Increase or Decrease?" Review of Economic Studies 60, pp.543-573. 
Buiter, Willem H. (1987), "Borrowing to Defend the Exchange Rate and the Timing and Magnitude of Speculative Attacks," Journal of International Economics 23, pp.221-240.

Caramazza, Francesco (1993), "French-German Interest Rate Differentials and Time-Varying Realignment Risk," Staff Papers 40, pp.567-583.

Chen, Zhaohui (1995), "Speculative Market Structure and the Collapse of an Exchange Rate Mechanism," unpublished manuscript, LSE.

Chen, Zhaohui and Alberto Giovannini (1993), "The Determinants of Realignment Expectations Under the EMS: Some Empirical Regularities," CEPR Discussion Paper No. 790.

Claessens, Stijn (1991), "Balance of Payments Crises in an Optimal Portfolio Model," European Economic Review 35, pp.81-101.

Commission of the European Communitie s, Directorate-General for Economic and Financial Affairs (1993), "The ERM in 1992," European Economy 54, pp.141-157.

Committee of Governors of the Central Banks of the Member States of the European Economic Community (1993a), Annual Report 1992, Basle: Committee of Governors.

Committee of Governors of the Central Banks of the Member States of the European Economic Community (1993b), "The Implications and Lessons to be Drawn from the Recent Exchange Rate Crisis -- Report of the Committee of Governors," processed, 21 April.

Connolly, M.B. (1986), "The Speculative Attack on the Peso and the Real Exchange Rate," Journal of International Money and Finance 5 (supp.), pp.117-130.

Connolly, M.B. and Dean Taylor (1983), "The Exact Timing of the Collapse of an Exchange Rate Regime and its Impact on the Relative Price of Traded Goods," Journal of Money, Credit and Banking 16, pp.194-207.

Cooper, Richard (1971), "Exchange Rate Devaluation in Developing Countries," Princeton Essays in International Finance no. 86, International Finance Section, Department of Economics, Princeton University.

Cooper, Richard N. (1990), "What Future for the International Monetary System?" in Yoshio Suzuki, Junichi Miyake and Mitsuiake Okabe (eds), The Evolution of the International Monetary System, Tokyo: University of Tokyo Press.

Cuikerman, A., M. Kiguel and L. Leiderman (1993), "The Choice of Exchange Rate Bands: Balancing Credibility and Flexibility," unpublished manuscript, Tel Aviv University. 
Cumby, Robert E. and Sweder van Wijnbergen (1989), "Financial Policy and Speculative Runs with a Crawling Peg: Argentina 1979-1981," Journal of International Economics 27, pp.111-127.

Dellas, Harris and Alan C. Stockman (1993), "Self-Fulfilling Expectations, Speculative Attacks and Capital Controls," Journal of Money, Credit and Banking 25, pp.721-730.

Dornbusch, Rudiger and Alejandro Werner (1994), "Mexico: Stabilization, Reform, and No Growth," Brookings Papers on Economic Activity 1, pp.253-316.

Drazen, Allan and Paul R. Masson (1994), "Credibility of Policies versus Credibility of Policymakers," Quarterly Journal of Economics 109, pp.735-754.

East, Roger (ed.), (various years) Keesing's Record of World Events, Cambridge, Longman.

Edwards, Sebastian (1989), Real Exchange Rates, Devaluation and Adjustment: Exchange Rate Policy in Developing Countries, Cambridge, Mass.: MIT Press.

Edwards, Sebastian (1993), "Devaluation Controversies in the Developing Countries," in Michael D. Bordo and Barry Eichengreen (eds), A Retrospective on the Bretton Woods System, Chicago: University of Chicago Press, pp.405-455.

Eichengreen, Barry (1994), International Monetary Arrangements for the 21st Century, Washington, D.C.: The Brookings Institution.

Eichengreen, Barry, Andrew K. Rose and Charles Wyplosz (1994a), "Speculative Attacks on Pegged Exchange Rates: An Empirical Exploration with Special Reference to the European Monetary System," in Matthew Canzoneri, Paul Masson and Vittorio Grilli (eds), Transatlantic Economic Issues, Cambridge: Cambridge University Press.

Eichengreen, Barry, Andrew K. Rose and Charles Wyplosz (1994b), "Is There a Safe Passage to EMU? Evidence from the Markets and a Proposal," in Jeffrey Frankel and Alberto Giovannini (eds), The Micro-Structure of Foreign Exchange Markets, Chicago: University of Chicago Press (forthcoming).

Eichengreen, Barry, James Tobin and Charles Wyplosz (1995), "Two Cases for Sand in the Wheels of International Finance," Economic Journal 105, pp.162-172.

Eichengreen, Barry and Charles Wyplosz (1993), "The Unstable EMS," Brookings Papers on Economic Activity 1, pp.51-143. 
Flood, Robert and Peter Garber (1984a), "Collapsing Exchange-Rate Regimes: Some Linear Examples," Journal of International Economics 17, pp.1-13.

Flood, Robert and Peter Garber (1984b), "Gold Monetization and Gold Discipline," Journal of Political Economy 92, pp.90-107.

Flood, Robert P. and Andrew K. Rose (1993) "Fixing Exchange Rates" CEPR DP \#838, NBER WP \#4503.

Gerlach, Stefan and Frank Smets (1994), "Contagious Speculative Attacks," CEPR Discussion Paper No. 1055 (November).

Girton, Lance and Don Roper (1977), "A Monetary Model of Exchange Market Pressure Applied to Postwar Canadian Experience," American Economic Review 67, pp.537-548.

Goldberg, Linda (1993), "Predicting Exchange Rate Crises: Mexico Revisited," Journal of International Economics (forthcoming).

Goldstein, Morris, David Folkerts-Landau, Peter Garber, Liliana Rojas-Suarez and Michael Spencer (1993), International Capital Markets, Part 1: Exchange Rate Management and International Capital Flows, Washington, D.C.: IMF.

Grilli, Vittorio (1986) "Buying and Selling Attacks on Fixed Exchange Rate Systems," Journal of International Economics 20, pp. 143-156.

Grilli, Vittorio, D. Masciandaro and Guido Tabellini (1991), "Political and Monetary Institutions and Public Financial Policies in the Industrial Countries," Economic Policy 13, pp.342-392.

Honohan, Patrick and Charles Conroy (1994), "Sterling Movements and Irish Pound Interest Rates," The Economic and Social Review 25, pp.201-220.

Jeanne, Olivier (1994), "Models of Currency Crises: A Tentative Synthesis with Special Reference to the 1992-3 EMS Crises," unpublished manuscript, ENPC-CERAS.

Kamin, Steve (1988), "Devaluation, External Balance and Macroeconomic Performance: A Look at the Numbers," Princeton Essays in International Finance no. 62, International Finance Section, Department of Economics, Princeton University.

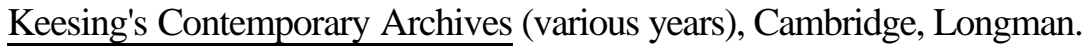

Krugman, Paul (1979), "A Model of Balance of Payments Crises," Journal of Money, Credit and Banking 11, pp.311-325. 
Lehment, Harmen (1994), "Speculative Pressure in the EMS: The Role of Capacity-Related Exchange-Rate Expectations," Kiel Institute for World Economics Working Paper No. 627 (April).

Masson, Paul R. (1995), "Gaining and Losing ERM Credibility: The Case of the United Kingdom," Economic Journal (forthcoming).

Meese, Richard and Kenneth Rogoff (1983), "Empirical Exchange Rate Models of the Seventies: Do They Fit Out of Sample?" Journal of International Economics 14, pp.3-24.

Melitz, Jacques (1994), "French Monetary Policy and Recent Speculative Attacks on the Franc," in David Cobham (ed.), European Monetary Upheavals, Manchester: Manchester University Press, pp.61-77.

Obstfeld, Maurice (1986), "Rational and Self-Fulfilling Balance-of-Payments Crises," American Economic Review LXXVI, pp.72-81.

Obstfeld, Maurice (1986), "Rational and Self-Fulfilling Balance-of-Payments Crises," American Economic Review LXXVI, pp.72-81.

Obstfeld, Maurice (1994), "The Logic of Currency Crises," National Bureau of Economic Research Working Paper No. 4640.

Ozkan, F. Gulcin and Alan Sutherland (1994), "A Model of the ERM Crisis," CEPR Discussion Paper No. 879 (January).

Ozkan, F. Gulcin and Alan Sutherland (1995), "Policy Measures to Avoid a Currency Crisis," Economic Journal 105, pp.510-519.

Penati, Alessandro and George Pennacchi (1989), "Optimal Portfolio Choice and the Collapse of a Fixed-Exchange Rate Regime," Journal of International Economics 27, pp.1-25.

Portes, Richard (1993), "EMS and EMU After the Fall," The World Economy 19, pp.1-16.

Rogoff, Kenneth and A. Siebert (1988), "Equilibrium Political Business Cycles" Review of Economic Studies 55, pp.1-16.

Rose, Andrew and Lars Svensson (1994), "European Exchange Rate Credibility Before the Fall," European Economic Review 38, pp.1185-1216.

Roubini, Nouriel and Jeffrey Sachs (1988), "Government Spending and Budget Deficits in the Industrial Countries," Economic Policy 8, pp.100-132. 
Roubini, Nouriel and Jeffrey Sachs (1989), "Political and Economic Determinants of Budget Deficits in the Industrial Economies," European Economic Review 33, pp.903-938.

Salant, Stephen W. and Dale W. Henderson (1978), "Market Anticipation of Government Policy and the Price of Gold," Journal of Political Economy 86, pp.627-648.

Thomas, Alun H. (1994), "Expected Devaluation and Economic Fundamentals," Staff Papers 41, pp.262-285.

Uribe, Martin (1995), "Real Exchange Rate Targeting and Macroeconomic Instability," unpublished manuscript, Board of Governors of the Federal Reserve System.

Weber, Axel (1994) 'Foreign Exchange Market Intervention and International Policy Coordination" CEPR Discussion Paper No. 1038.

Weymark, Diana N. (1994), "Estimating Exchange Market Pressure and the Degree of Exchange Market Intervention for Canada," unpublished manuscript, Western Washington University.

Williamson, John and Randall Henning (1994), "Managing the Monetary System," in Peter B. Kenen (ed.), Managing the World Economy Fifty Years After Bretton Woods, Washington, D.C.: Institute for International Economics, pp.83-112.

Willman, Alpo (1988), "The Collapse of the Fixed Exchange Rate Regime with Sticky Wages and Imperfect Substitutability Between Domestic and Foreign Bonds," European Economic Review 32, pp.1817-1838.

Wyplosz, Charles (1986), "Capital Controls and Balance of Payments Crises," Journal of International Money and Finance 5, pp.167-179. 
Table I: Political Events and Exchange Rate Episodes

\begin{tabular}{|c|c|c|c|c|c|c|c|c|}
\hline & $\begin{array}{l}\chi^{2} \text { Test of } \\
\text { Ind (df) }\end{array}$ & $\begin{array}{l}\text { Tranquilli } \\
\text { ty }\end{array}$ & $\begin{array}{l}\text { Failed } \\
\text { Attack } \\
\end{array}$ & $\begin{array}{l}\text { Deval- } \\
\text { uation }\end{array}$ & $\begin{array}{l}\text { Reval- } \\
\text { uation } \\
\end{array}$ & Flotation & Fixing & $\begin{array}{l}\text { Other } \\
\text { Event } \\
\end{array}$ \\
\hline Sample & $\mathrm{n} / \mathrm{a}$ & 2516 & 61 & 81 & 20 & 33 & 33 & 56 \\
\hline $\begin{array}{l}\text { Left-wing } \\
\text { Gov't }\end{array}$ & $10(5)$ & 79 & 4 & 8 & 2 & 0 & 2 & 3 \\
\hline Elections & $6(5)$ & 177 & 6 & 8 & 2 & 0 & 3 & 4 \\
\hline $\begin{array}{l}\text { Change in } \\
\text { Gov't }\end{array}$ & $4(5)$ & 71 & 2 & 6 & 1 & 0 & 1 & 3 \\
\hline $\begin{array}{l}\text { Gov't } \\
\text { Victory }\end{array}$ & $3(6)$ & 118 & 3 & 3 & 1 & 0 & 3 & 2 \\
\hline $\begin{array}{l}\text { Past Gov } \\
\text { Victory }\end{array}$ & $5(6)$ & 462 & 10 & 12 & 3 & 8 & 3 & 7 \\
\hline $\begin{array}{l}\text { Fut Gov } \\
\text { Victory }\end{array}$ & 8 & 448 & 7 & 17 & 5 & 4 & 10 & 13 \\
\hline $\begin{array}{l}\text { Gov't } \\
\text { Defeat }\end{array}$ & $8(5)$ & 71 & 2 & 6 & 1 & 0 & 1 & 3 \\
\hline $\begin{array}{l}\text { Past Gov } \\
\text { Defeat } \\
\end{array}$ & $33 * *(6)$ & 271 & 6 & 20 & 8 & 4 & 5 & 9 \\
\hline $\begin{array}{l}\text { Fut Gov't } \\
\text { Defeat }\end{array}$ & 9 & 284 & 13 & 13 & 1 & 3 & 4 & 9 \\
\hline $\begin{array}{l}\text { New Fin } \\
\text { Minister }\end{array}$ & 7 & 158 & 3 & 9 & 3 & 4 & 2 & 4 \\
\hline $\begin{array}{l}\text { Past New } \\
\text { Fin Min }\end{array}$ & $24 * *$ & 571 & 27 & 25 & 6 & 12 & 8 & 19 \\
\hline $\begin{array}{l}\text { New Fut } \\
\text { Fin Min } \\
\end{array}$ & $19 * *$ & 581 & 25 & 24 & 3 & 12 & 12 & 16 \\
\hline $\begin{array}{l}\text { Capital } \\
\text { Controls }\end{array}$ & $26 * *(6)$ & 512 & 21 & 11 & 2 & 4 & 2 & 8 \\
\hline $\begin{array}{l}\text { No } \\
\text { Controls }\end{array}$ & $\mathrm{n} / \mathrm{a}$ & 1116 & 34 & 62 & 14 & 24 & 24 & 38 \\
\hline
\end{tabular}

Two asterisks denote statistical significance at the $1 \%$ level. 
Table II: Multinomial Logit Estimation of Exchange Rate Episodes

Coefficient Estimates (P-value of Null Ho: Coefficient=0)

\begin{tabular}{l|l|ll|l|l|l} 
& Failed Attack & Devaluation & Revaluation & Flotation & Fixing & Other Event \\
\hline Past Crisis & $-3.5(.00)$ & $.27(.34)$ & $.03(.97)$ & $-.61(.33)$ & $-1.4(.09)$ & $.33(.44)$ \\
\hline Past Event & $.77(.51)$ & $.14(.77)$ & $-1.4(.11)$ & $.55(.61)$ & $20 .(.00)$ & $-1.1(.03)$ \\
\hline Past Controls & $3.9(.00)$ & $-2.2(.02)$ & $3.2(.05)$ & $-.62(.80)$ & $.89(.79)$ & $-.58(.74)$ \\
\hline Past Gov Win & $-.44(.59)$ & $-.10(.82)$ & $-.12(.88)$ & $.12(.85)$ & $-.69(.55)$ & $.51(.38)$ \\
\hline Past Gov Loss & $1.1(.11)$ & $.88(.01)$ & $1.9(.01)$ & $.44(.55)$ & $1.2(.09)$ & $.64(.21)$ \\
\hline Credit Lag & $.02(.63)$ & $.01(.74)$ & $-.11(.15)$ & $-.03(.51)$ & $-.18(.00)$ & $.01(.74)$ \\
\hline Inflation Lag & $-.21(.03)$ & $-.09(.07)$ & $-.16(.23)$ & $-.13(.16)$ & $-.16(.13)$ & $.03(.73)$ \\
\hline Growth Lag & $.12(.30)$ & $-.08(.30)$ & $.01(.96)$ & $-.12(.43)$ & $.14(.39)$ & $-.15(.21)$ \\
\hline Employ. Lag & $.53(.00)$ & $.02(.87)$ & $-.34(.30)$ & $-.10(.68)$ & $.62(.02)$ & $-.02(.94)$ \\
\hline Unemp. Lag & $.17(.65)$ & $.22(.27)$ & $.53(.34)$ & $.07(.85)$ & $.06(.90)$ & $.13(.68)$ \\
\hline Budget Lag & $-.05(.77)$ & $.09(.22)$ & $.03(.88)$ & $-.01(.94)$ & $-.19(.29)$ & $-.24(.03)$ \\
\hline C/Acc Lag & $-.05(.68)$ & $-.22(.00)$ & $.12(.43)$ & $.15(.14)$ & $-.05(.69)$ & $.12(.33)$ \\
Fut Controls & $-3.3(.01)$ & $2.9(.00)$ & $-.88(.49)$ & $1.3(.61)$ & $2.2(.51)$ & $1.7(.34)$ \\
\hline Fut Gov Win & $.43(.63)$ & $.53(.13)$ & $.03(.97)$ & $-1.1(.33)$ & $1.3(.07)$ & $.70(.16)$ \\
\hline Fut Gov Loss & $1.8(.01)$ & $.30(.41)$ & $-33 .(1.0)$ & $-.08(.92)$ & $-.89(.43)$ & $.70(.18)$ \\
\hline Credit Lead & $-.01(.78)$ & $-.03(.16)$ & $.06(.13)$ & $.05(.14)$ & $-.04(.49)$ & $.01(.75)$ \\
\hline Inflation Lead & $.38(.00)$ & $.05(.34)$ & $.03(.82)$ & $.16(.05)$ & $.23(.02)$ & $-.05(.52)$ \\
\hline Growth Lead & $.27(.03)$ & $.04(.54)$ & $.09(.63)$ & $.14(.29)$ & $.39(.01)$ & $-.14(.27)$ \\
\hline Employ. Lead & $.31(.08)$ & $-.13(.39)$ & $-.08(.81)$ & $-.25(.29)$ & $-.39(.24)$ & $.20(.33)$ \\
\hline Unemp. Lead & $-.02(.97)$ & $-.17(.37)$ & $-.46(.40)$ & $-.12(.74)$ & $.09(.85)$ & $-.18(.56)$ \\
\hline Budget Lead & $.14(.35)$ & $-.17(.02)$ & $-.00(1.0)$ & $.08(.57)$ & $.15(.40)$ & $.14(.20)$ \\
\hline C/Acc Lead & $.12(.32)$ & $.14(.04)$ & $.09(.55)$ & $-.24(.06)$ & $.02(.91)$ & $.04(.68)$ \\
& & & & & & \\
\hline
\end{tabular}

Maximum Likelihood Estimation.

No. Obs. $=1399$. McFadden's $\mathrm{R}^{2}=.18$

Hypothesis Tests for Cells: [Chi-squared df] (P-value of Null Ho: Coefficient=0)

All Slopes $=0:{ }^{2}[132]=262(.00)$

Failed Attacks=Tranquillity: ${ }^{2}[22]=44(.00)$

Devaluations $=$ Tranquillity: $\chi_{2}^{2}[22]=54(.00)$

Revaluations=Tranquillity: $\chi^{2}[22]=25(.31)$

Flotations $=$ Tranquillity: $\chi^{2}[22]=28(.17)$

Fixings=Tranquillity: $\chi^{2}[22]=7200(.00)$

Other Events=Tranquillity: $\chi^{2}[22]=21(.51)$

Hypothesis Tests for Irrelevance of Regressors:

Irrelevance of Lagged Terms: $\chi^{2}[72]=459(.00)$; of Lead Terms: $\chi^{2}[60]=100(.00)$

Irrelevance of Past Crises: $\chi^{2}[6]=15$ (.02); of Past Events : $\chi^{2}[6]=144$ (.00)

Gov't Victory:

Gov't Defeat:

Credit Growth Differential:

Inflation Differential:

Real GDP Growth Differential:

Employment Growth Differential

Unemployment Rate Differential

Budget/GDP Differential

Current Account/GDP Differential
Lag: $\chi^{2}[6]=2(.95)$

Lag: $\chi_{2}^{2}[6]=21(.00)$

Lag: $\chi_{2}^{2}[6]=12(.07)$

Lag: $\chi_{2}^{2}[6]=13(.04)$

Lag: $\chi_{2}^{2}[6]=5(.53)$

Lag: $\chi^{2}[6]=15(.02)$

Lag: $\chi^{2}[6]=2(.87)$

Lag: $\chi_{2}^{2}[6]=8(.25)$

Lag: $\chi^{2}[6]=14(.03)$
Lead: $\chi_{2}^{2}[6]=8(.22)$

Lead: $\chi_{2}^{2}[6]=9(.15)$

Lead: $\chi_{2}^{2}[6]=7(.30)$

Lead: $\chi^{2}[6]=25(.00)$

Lead: $\chi^{2}[6]=14(.02)$

Lead: $\chi_{2}^{2}[6]=8(.27)$

Lead: $\chi^{2}[6]=2(.93)$

Lead: $\chi^{2}[6]=9(.16)$

Lead: $\chi^{2}[6]=9(.15)$ 


\section{Data Appendix}

Macroeconomic and financial data are mostly taken from the International Monetary Fund's International Financial Statistics (IFS). The data set is quarterly, spanning 1959 through 1993 for twenty industrial countries. ${ }^{55}$ The data have been checked for transcription and other errors and corrected. For most purposes these variables are transformed into differential percentage changes by taking differences between domestic and German annualized first-differences of natural logarithms, multiplied by 100 . We employ the following variables: total non gold international reserves (IFS line 1ld); period-average exchange rates (line rf); short-term interest rates (money market rates [line 60b] where possible, discount rates otherwise [line 60]); exports and imports (both measured in dollars, lines 70d and 71d respectively); the current account (line 77a.d, converted to domestic currency) and the central government budget position (line 80), both measured as percentages of nominal GDP (frequently line 99a); long-term government bond yields (line 61); a nominal stock market index (line 62, which sets 1990=100); domestic credit (line 32); M1 (line 34); M2 (line 35+ M1); the CPI (line 64); and real GDP (usually line 99a.r). We also use the real effective exchange rate as a measure of competitiveness (line reu, which uses normalized relative unit labor costs), though this variable is only available from 1975.

55 The countries we consider are (in order of IMF country number): the USA, UK, Austria, Belgium, Denmark, France, Italy, Netherlands, Norway, Sweden, Switzerland, Canada, Japan, Finland, Greece, Ireland, Portugal, Spain and Australia, along with our center country, Germany. 
Data on total employment, the unemployment rate, and the business sector wage rate were drawn from the OECD's Main Economic Indicators. ${ }^{56}$

56 As an alternative measure of fiscal policy, we could employ the OECD's measures of fiscal impulses. These data have advantages: they cover the entire government, are cyclically adjusted, and measure the primary budget position. On the other hand, they are only available annually, and were typically unavailable to market participants. 
Deviation of Differentials from Tranquillity; Samples not Domparable Industrial Country Fanel, 1959-1993

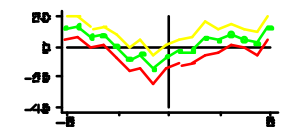

sthathe in FX Prestrves

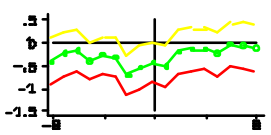

Gov't घudoet (T. GDP)

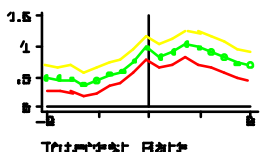

Intmerest Pate

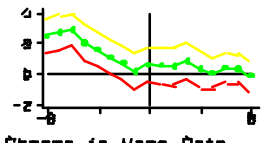

Change in Name Bate

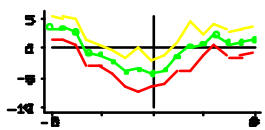

Chenge in \$ Expgitts

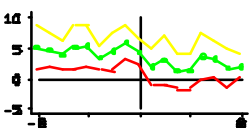

Lredit Growith

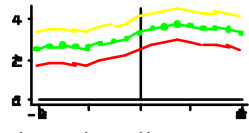

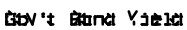

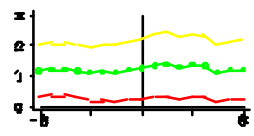

unmapjoy ment Poxto

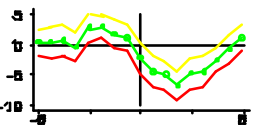

Chenge jin Imports Current $\Delta$ ecount $2 x$ GDPs

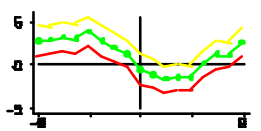

Yíl Growtin

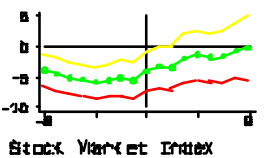

Iristex

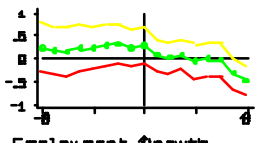

Employ mont arawth

deviation band
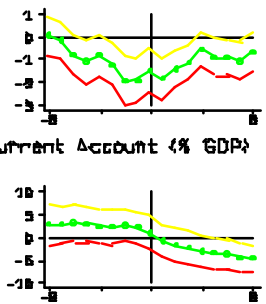

Heol Ettect. FX Inotex
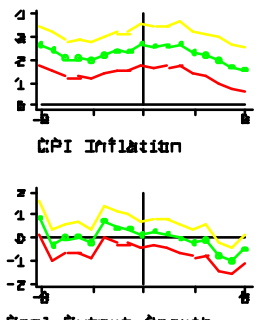

Aasl butput Growth

Movements B Quarters Before anind After (81) Clevaluations

\section{Figure 1: Exchange Rate Devaluations}

Deviation of Differentials from Tranquillity; Samples not Domparable Industriel Country Fanel, 1959-1993

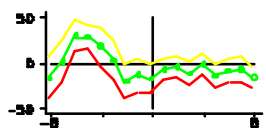

Ghathe in FX Aleserves

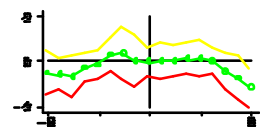

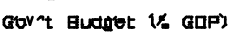

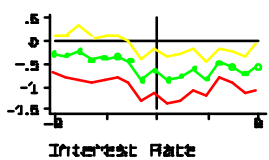

Iritereste pate

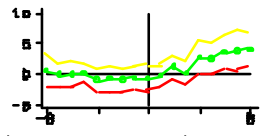

Change in Nage Pate

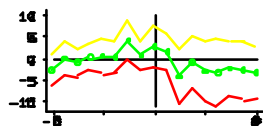

Chenge in Expgints

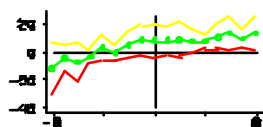

trodit Growith

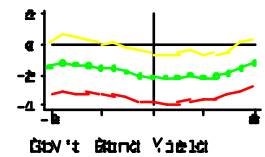

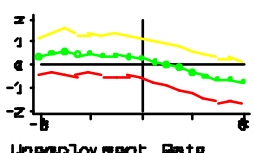

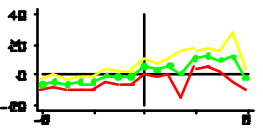

Chenge jin I Indorts

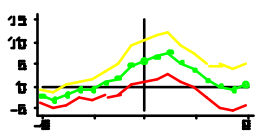

Yrí trowtin

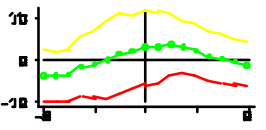

Etack Mastet Irosex

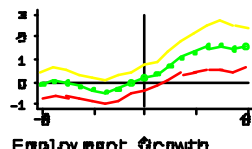

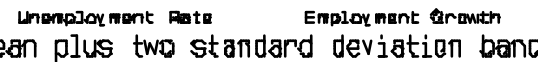

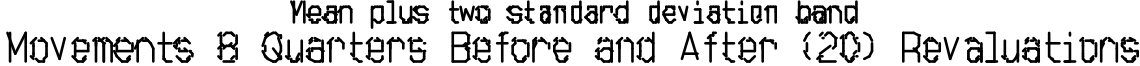

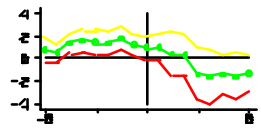

arretent secount \&\% GDPs

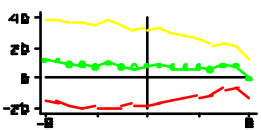

Fied Ettect. FX Inder
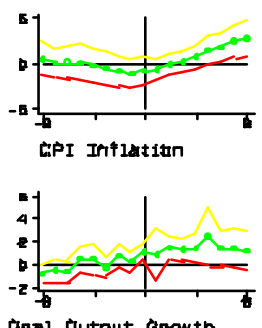

\section{Figure 2: Exchange Rate Revaluations}


Deviation of Differentials from Tranquillity: Semples not Comparabile Industrial country Panel, 1959-1993

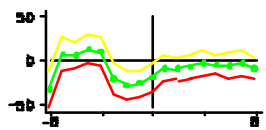

Choinge in FX Festerves

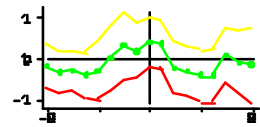

Govat Buderet $(1$. EDP)

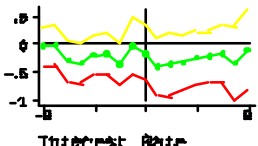

Iits.urest katse

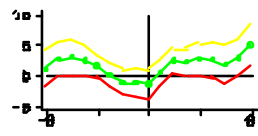

Changa in Naga date

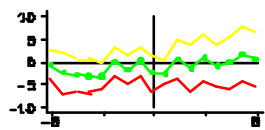

Chomge in 8 Exports

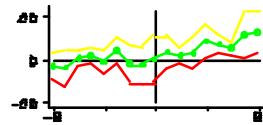

Credit Growtri

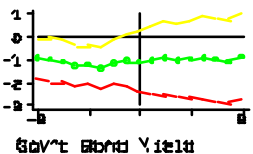

covat abons $Y_{1}$ iels

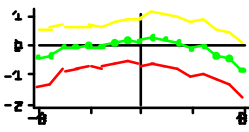

Unemploynent dato

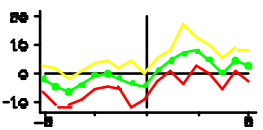

Chonge in \& Imoorts

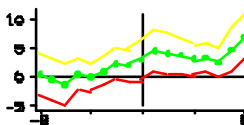

Mi Branten

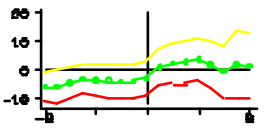

Stock Vlatrket Inclex

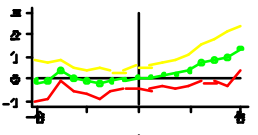

Enoloymant srawth

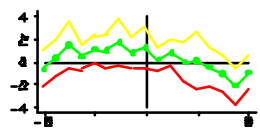

Current Ateount or GCP)

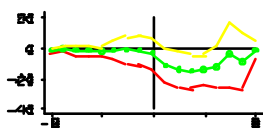

Fed Effett. FX Indrex
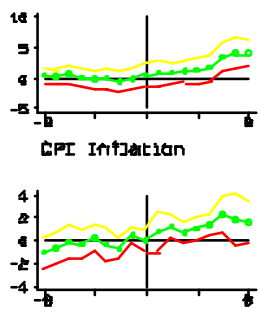

Haa] Dutput Arowth

Movements 8 Duarters Before and After (33) Flotations

\section{Figure 3: Flotations of Exchange Rates}

Deviation of Differentials from Tranquillity; Samples not Comparable Industrial Country Panel, 1959-1993

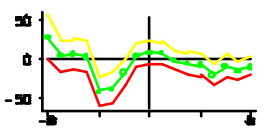

cinence in FX reservas

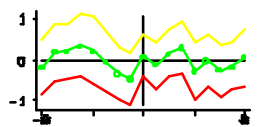

Bav't Buddet [\% gap]
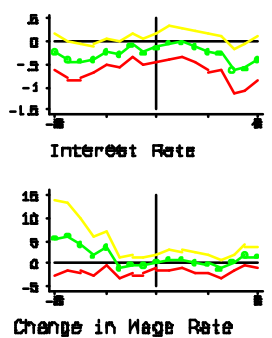

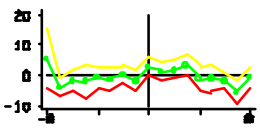

Criange in 5 Exporits

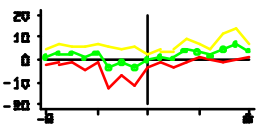

Credit Branth

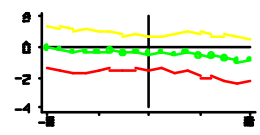

Eov't Ednd Yield

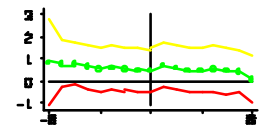

Unenployment Rate Mean plus two s
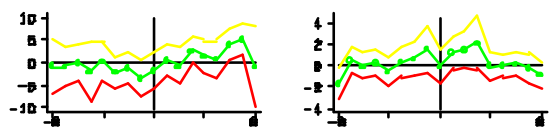

Chenge in E Imparts

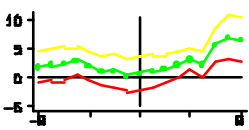

M1 Brawth

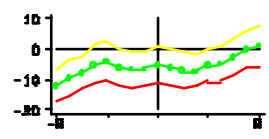

Stack Merket Index

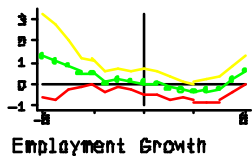

Enploynent Growth

deviation Dani

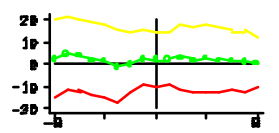

Peal Effec. FX Index

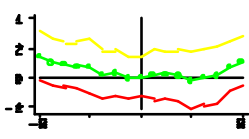

CPI Influtjon

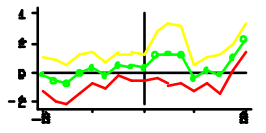

Reg] Output Enauth

Movements 8 Quarters Before and After (33) Fixings

\section{Figure 4: Fixings of Exchange Rates}


Deviation of Differentials from Trenquillity; Semples not Comperabile Industrial Country Panel, 1959-1993
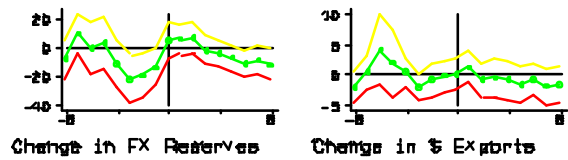

Chemge in 5 Exports
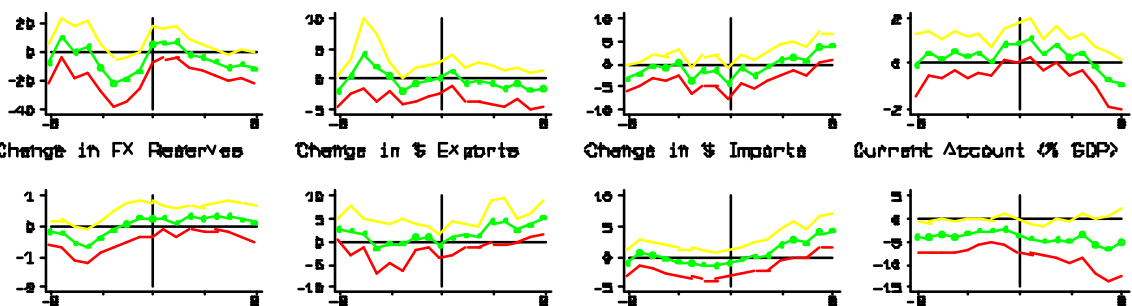

Gov't घuderet (Y. EOP)

Credit Growtri

Chongt in \& Imports Urreint AtEQunt to GCP)
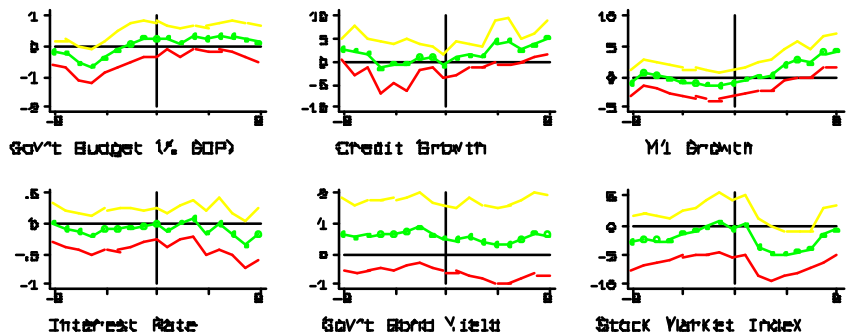

Mis Browten

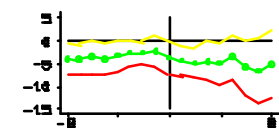

Feal Ef tett. FX Ingtex
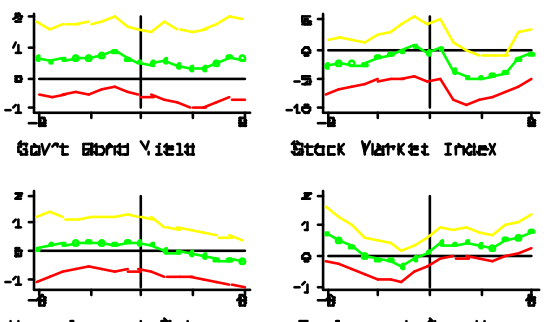

stock Vlatrket Inclex
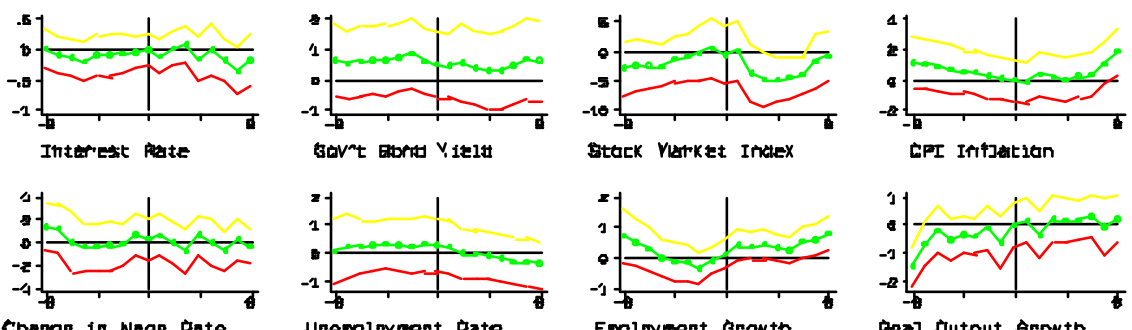

Emaloymant srawth

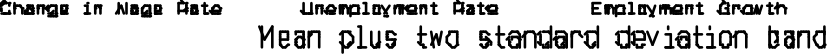

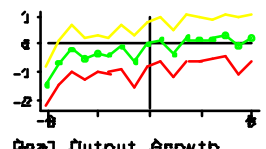

Baaj Dutput Arowth

Movements 8 Duarter's Around (56) Other Events

\section{Figure 5: Other Changes in Exchange Rate Regimes}

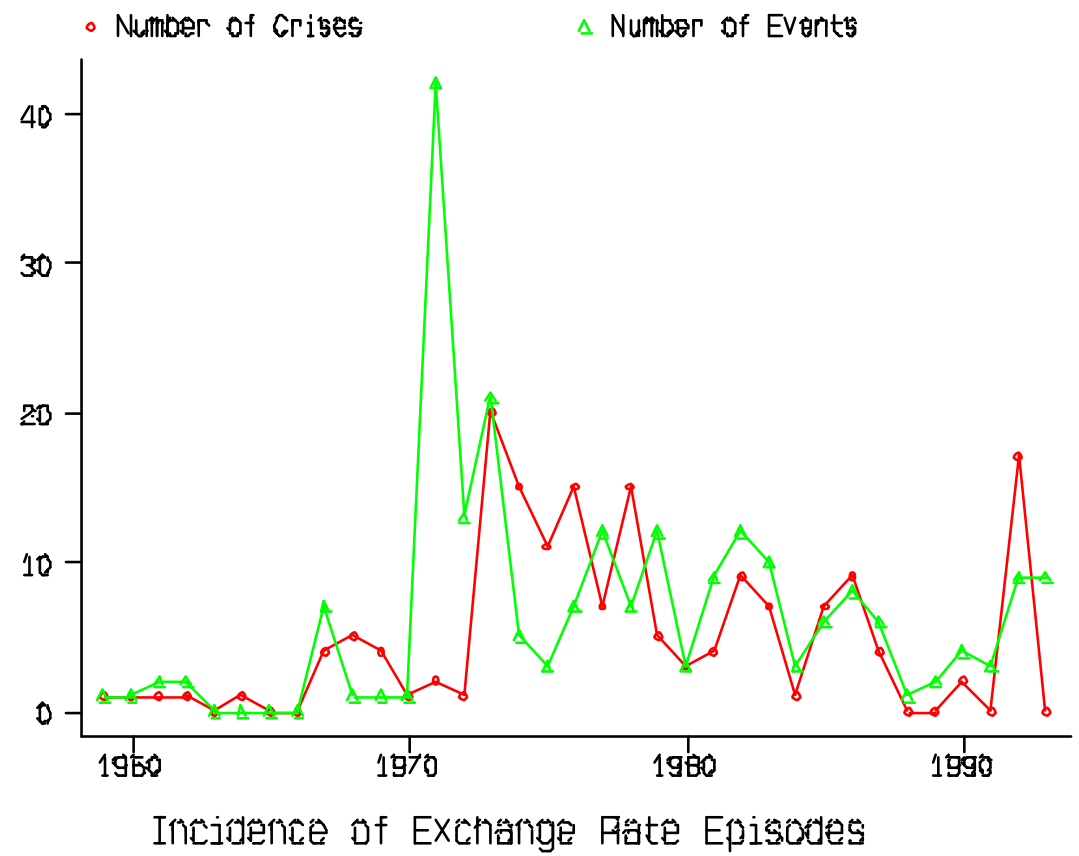

Figure 6: The Timing of Speculative Attacks 
Deviation of Differentials from Tranquillity: Semples not Comparabile Industrial Country Panel, 1959-1993

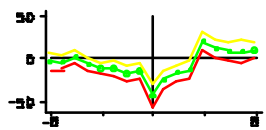

Chathge in FX Federves

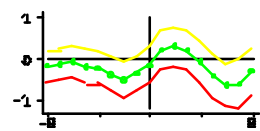

Govit Budeet $(\%$ EOP)

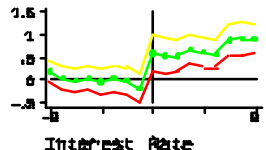

Inturest perts

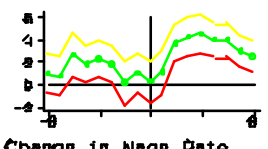

Chango in Nage Bate

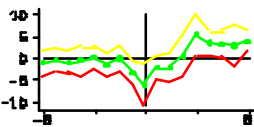

Chenge in Exports

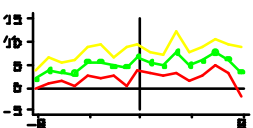

Credit Growtri

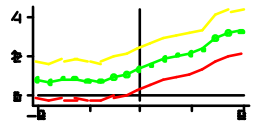

bav't aborss $Y$ iels

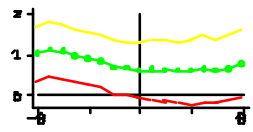

Unemployment Dato

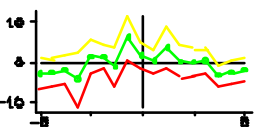

Chonge in s Imoorts

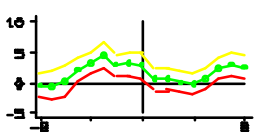

Mis Erowen

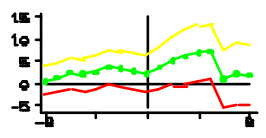

stock Viatoket Inclex

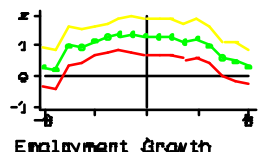

Employmant srawth

desviation band

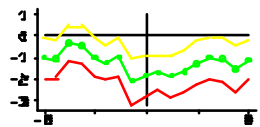

Current Ateount or GCP)

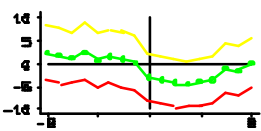

Red Ef fett. FX InUtex

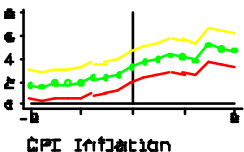

CPI I个ifuation

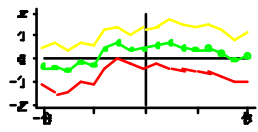

Baaj Dutput Arowth

Movements 8 Quartars Before and After (78) Crises

\section{Figure 7: Exchange Rate Crises}

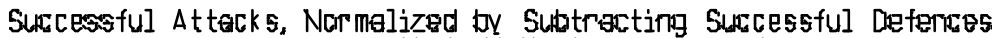
Iridustrial Gountry Penel, 1959-1999; Semples not Compareble

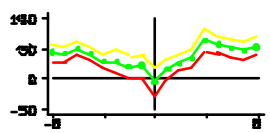

Cheituge in FX Alesterves

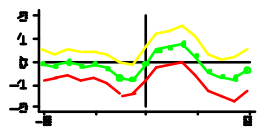

Bavnt Buderet $(\%$ EGP)

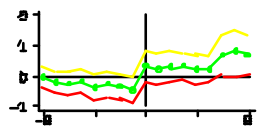

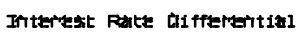

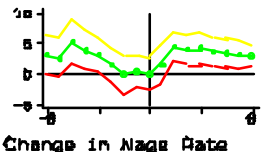

in Nagd Date

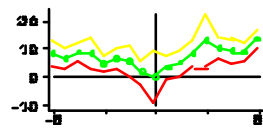

Change in \$ Exports

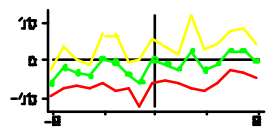

CPecht Browth

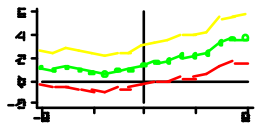

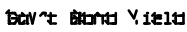

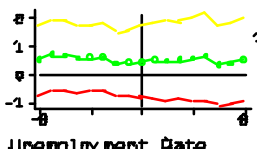

Unemplay mant date

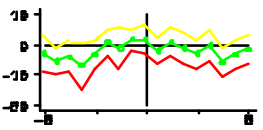

Charke in s Iroorts

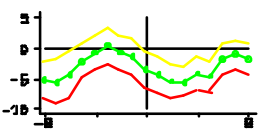

Mí Erowith

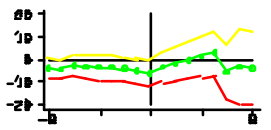

gratax Vurtoket Inelex

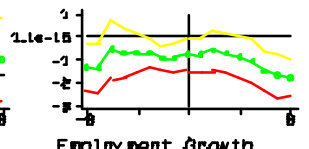

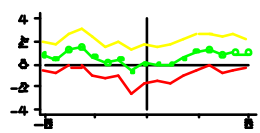

Gumerit Aecevant of GEP)

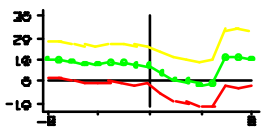

मө: Effett. FX Index
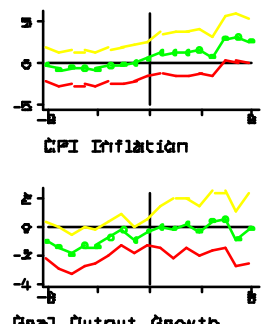

Roa] Dutput Browth

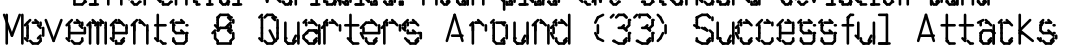

Figure 8: The Differences Between Successful Attacks and Successful Defences 
Deviation of Differentials from Trenquility: Semples not Comparable EV/S Panel، 197'-1993

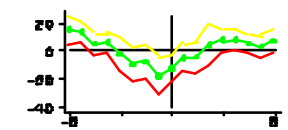

Chothge in FX Federves

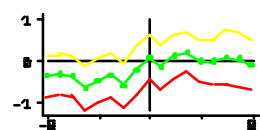

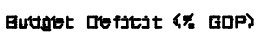

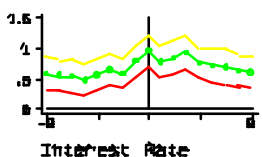

Int:urest kate

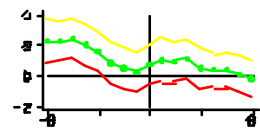

Change in Naga Bate

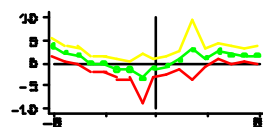

Chenge in 5 Exports

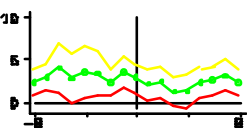

Credit Browtri

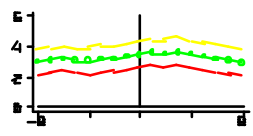

bovat aboras $Y$ izls

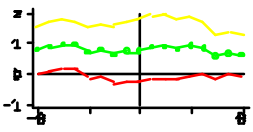

Unemployment Bato

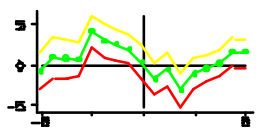

Chonge in s Imports Curreint Ateount $4 \%$ GCP)

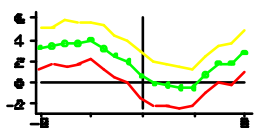

Mis Browten
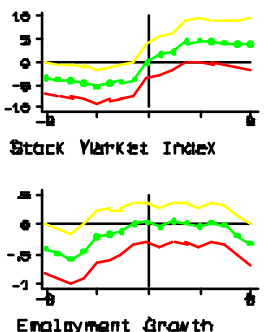

Emoloymant srawth
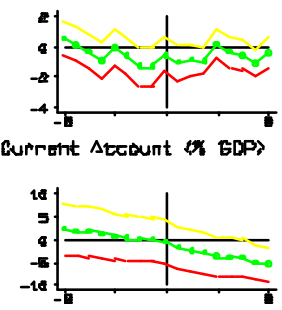

Feal Ef tett. FX Indtex
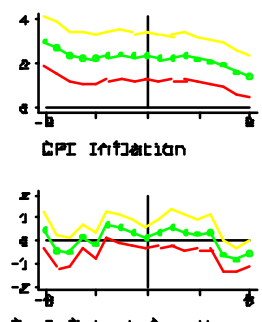

Baaj Output Browth

Migvements 8 Buarters Before and After (5屯) Devaluations

\section{Figure 9: EMS Devaluations}

Differential Variables: Comparison of Mobility to Capital controls Indurstrial Country Famel, 1950-1993; Samples not Compareble
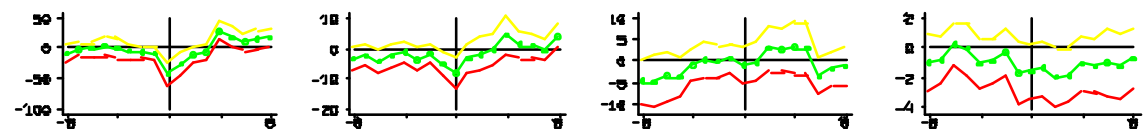

Chango in FX Degervas

Chango in a Experta

Changg in s Inporto
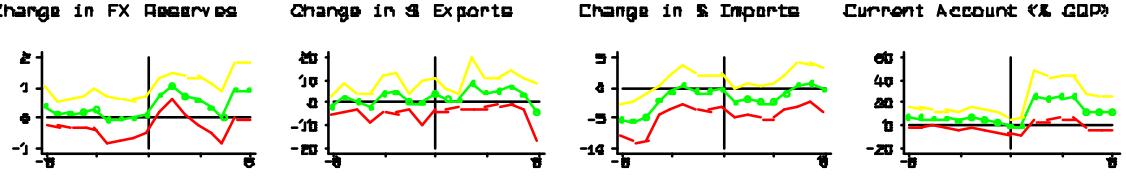

Eradibt Growth

V1 Irawith

Dod Effect. FX Index
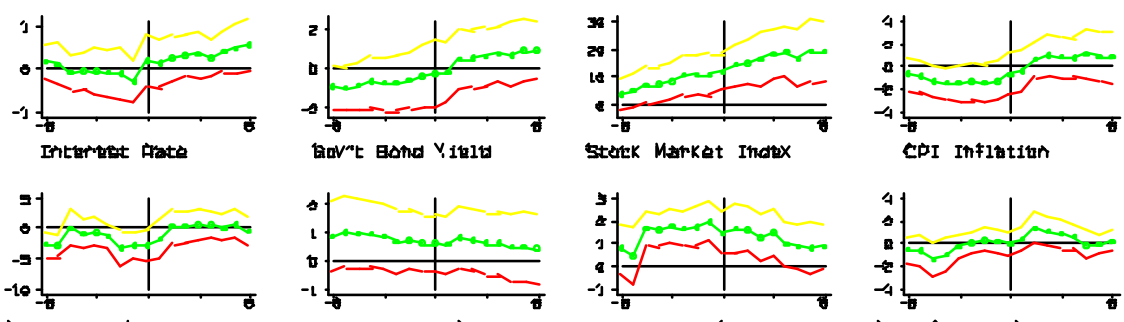

Unamploy mant bata

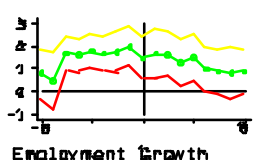

Emplaynont trowth Mean plus two standard daviation ban

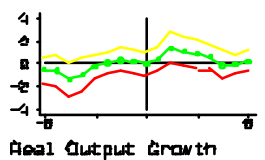

Movernents 8 buarters Before ard Aftar

(31) Crises

Figure 10: Crises wi thout and with Capital Controls 